\title{
Phylogenetic insights into Andean plant diversification
}

\author{
Federico Luebert ${ }^{1,2 *}$ and Maximilian Weigend ${ }^{1}$ \\ ' Nees-Institut für Biodiversität der Pflanzen, Universität Bonn, Bonn, Germany \\ ${ }^{2}$ Departamento de Silvicultura y Conservación de la Naturaleza, Universidad de Chile, Santiago, Chile
}

\section{Edited by:}

Norman A. Johnson, University of

Massachusetts - Amherst, USA

Reviewed by:

Guo-Bo Chen, University of

Queensland, Australia

Michael O. Dillon, Field Museum or

Natural History, USA

\section{*Correspondence:}

Federico Luebert, Nees-Institut für

Biodiversität der Pflanzen,

Universität Bonn, Meckenheimer

Allee 170, 53115 Bonn, Germany

e-mail: fluebert@uni-bonn.de
Andean orogeny is considered as one of the most important events for the development of current plant diversity in South America. We compare available phylogenetic studies and divergence time estimates for plant lineages that may have diversified in response to Andean orogeny. The influence of the Andes on plant diversification is separated into four major groups: The Andes as source of new high-elevation habitats, as a vicariant barrier, as a North-South corridor, and as generator of new environmental conditions outside the Andes. Biogeographical relationships between the Andes and other regions are also considered. Divergence time estimates indicate that high-elevation lineages originated and diversified during or after the major phases of Andean uplift (Mid-Miocene to Pliocene), although there are some exceptions. As expected, Andean mid-elevation lineages tend to be older than high-elevation groups. Most clades with disjunct distribution on both sides of the Andes diverged during Andean uplift. Inner-Andean clades also tend to have divergence time during or after Andean uplift. This is interpreted as evidence of vicariance. Dispersal along the Andes has been shown to occur in either direction, mostly dated after the Andean uplift. Divergence time estimates of plant groups outside the Andes encompass a wider range of ages, indicating that the Andes may not be necessarily the cause of these diversifications. The Andes are biogeographically related to all neighboring areas, especially Central America, with floristic interchanges in both directions since Early Miocene times. Direct biogeographical relationships between the Andes and other disjunct regions have also been shown in phylogenetic studies, especially with the eastern Brazilian highlands and North America. The history of the Andean flora is complex and plant diversification has been driven by a variety of processes, including environmental change, adaptation, and biotic interactions.

Keywords: Andes, divergence times, orogeny, phylogeny, plants, uplift

\section{INTRODUCTION}

The uplift of the Andes is considered as one of the most important events in the biogeographical history of the Neotropical biota (Hoorn et al., 2010) and the tropical Andes are one of the most diverse areas on earth in terms of vascular plant species (Barthlott et al., 2005). Gentry (1982) suggested that Andean uplift is responsible for nearly half of the Neotropical plant species diversity (Figure 1). Due to its geographical setting in the South American continent, the Andes have been proposed to act as a corridor, promoting North-South exchange of biotic elements, as a barrier, generating both East-West and internal vicariance, and as promoter of speciation, with new high elevation environments becoming available during their formation (Simpson, 1975, 1983; Luebert et al., 2009, 2011b; Antonelli and Sanmartín, 2011b; Hoorn et al., 2013). The rising Andes also influenced climatic and hydrological conditions at a continental level (Hartley, 2003; Blisniuk et al., 2005; Hoorn et al., 2010), affecting the evolutionary history of species groups outside the mountain chain (Antonelli et al., 2009). Currently, two major problems limit our understanding of the effects of the Andes and their orogeny on plant diversification: the scarcity of dated phylogenies (Antonelli and Sanmartín, 2011b) and the controversy surrounding the detailed sequence and timing of the Andean orogeny (cf. Garzione et al., 2008; Ehlers and Poulsen, 2009). The purpose of this review is to offer a synopsis of Andean plant diversifications as known today based on phylogenetic studies. It will become apparent that there are now a wider range of dated phylogenies than commonly assumed. Conclusions obtained from these phylogenies can also contribute to the debate about the timing of Andean uplift.

A precise definition of "Andes" is necessary to circumscribe the scope of this review. We follow the operational concept adopted by Nagy and Grabherr (2009), which includes the mountain regions from Venezuela to southern Chile and Argentina. This definition coincides with Körner et al. (2011), in which mountains are defined by the roughness of the landscape rather than a given elevation, which is useful for mountain chains such as the Andes with a long North-South extension and dramatic differences in elevation, especially toward the South. Absolute elevation of the thermal and vegetation belts on the mountains decreases with increasing latitude (Körner, 1998). In this circumscription, the Andes comprise the biogeographical provinces of Páramo, Puna, Yungas, Prepuna, and Subandean Patagonia 

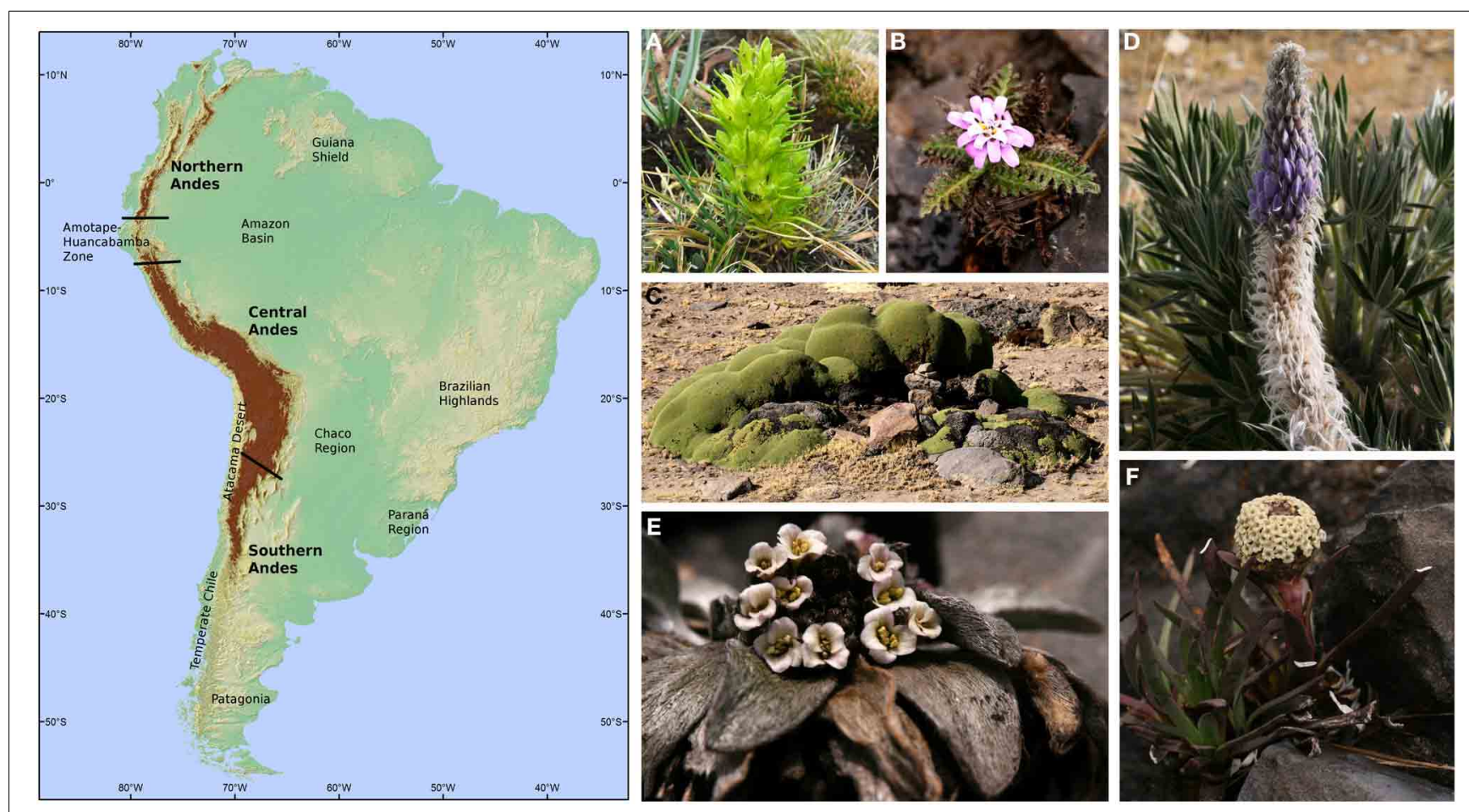

FIGURE 1 | Left panel: South American map showing the major geographical Andean units discussed in the text and approximate location of the most commonly used geographical areas. Brown area are elevations above 3000 m. Right panel: Selected high Andean plants. (A) Gentianella thyrsoidea (Gentianaceae); (B) Perezia pinnatifida (Asteraceae); (C) Azorella compacta (Apiaceae); (D) Lupinus weberbaueri (Fabaceae); (E) Draba weberbaueri (Brassicacae); (F) Valeriana globularis (Valerianaceae). Photos by H. H. Hilger. as defined in Morrone (2001). Within this region, three major geographical units can be identified: The Northern, the Central, and the Southern Andes (Figure 1, see Weigend, 2002). These units are also biogeographically meaningful. The Northern Andes comprise the mountains of Venezuela, Colombia, Ecuador, and the extreme North of Peru. At their southern edge a transition zone, the Amotape-Huancabamba zone, has been considered as a North-South biogeographical barrier, with high richness and endemism and many high-elevation groups reaching their northern and southern limits in this region (Weigend, 2002, 2004; Weigend et al., 2005). The Amotape-Huancabamba zone might represent a dispersal barrier for high-elevation lineages under current climatic conditions. Support for this idea has been found in the distribution of groups such as Lithospermum (Boraginaceae; Weigend et al., 2010), Macrocarpea (Gentianaceae; Struwe et al., 2009), Nasa (Loasaceae; Weigend, 2002), Peperomia (Piperaceae; Symmank et al., 2011). The Central Andes are situated between the Amotape-Huancabamba zone and the southern limit of the dry Puna around $25-29^{\circ} \mathrm{S}$, where the precipitation regime changes from summer-rainfall to winter-rainfall (Luebert and Pliscoff, 2006), which is paralleled by floristic turnover (Villagrán et al., 1983; Martínez-Carretero, 1995; Arroyo et al., 1997, 1998). Here, aridity has been suggested as an environmental filter for Andean elements distributed to the North and to the South of this zone (Villagrán et al., 1983). Finally, the Southern Andes include the remaining Andean zones south of $29^{\circ} \mathrm{S}$ where elevation tends to decrease from North to South (Pankhurst and
Herve, 2007) an effect that-for plants—is compensated by latitude. Thus, "high-Andean flora" can be found from its northern limit in Colombia/Venezuela to the southern tip of South America (Troll, 1968). In spite of this subdivision, there are plant groups that are distributed along the entire Andes. This may suggest that the barriers identified do not act as filters for the dispersal of all plant groups, or that they developed after the respective groups occupied their present range. Dated phylogenies interpreted in the light of Andean geological history can contribute to clarifying this kind of questions.

Several articles based on geophysical and paleobotanical information argue for the "rapid rise model," suggesting a recent and sudden uplift of the Andes, with more than half of the current elevation of the Central Andes uplifted between 10 and $6 \mathrm{Ma}$ (Gregory-Wodzicki, 2000; Graham et al., 2001; Ghosh et al., 2006; Garzione et al., 2008; Leier et al., 2013). The rapid rise model has generated considerable controversy and some authors have seriously challenged it. Ehlers and Poulsen (2009) suggest that paleoaltimetric estimates must be corrected with paleoclimatic data before the uplift history of the Andes can be reconstructed. According to Ehlers and Poulsen (2009), such correction would result in a more gradual uplift since, at least, Oligocene times and with most of the current elevation reached before $25 \mathrm{Ma}$. Other authors have suggested that the rapid rise model is at odds with geological evidence (e.g., Sempere et al., 2006; Hartley et al., 2007), but these authors place an emphasis on methodological issues and on the necessity of re-evaluating elevation estimates 
rather than on explicitly proposing new dates for the Andean uplift.

In spite of the controversy, all of these views are an oversimplification if applied to the Andes as a whole. The evidence supporting one or the other view comes from the central Andean plateau, but there are studies indicating that the timing of the Andean uplift varies along its extension from North to South. While in the Northern Andes the timing of the uplift should be reflected in its different tectonic history (Gregory-Wodzicki, 2000), studies show that the northern Andean uplift appears to have been approximately simultaneous with the Central Andes, or even younger (Bayona et al., 2008; Bermúdez et al., 2010; Mora et al., 2010; Erikson et al., 2012). Some studies show that the uplift rate decreased toward the end of the Pliocene (Erikson et al., 2012) with a renewal of the uplift during Quaternary times (Regard et al., 2010; Rodríguez et al., 2013), and in general the Venezuelan Andes seem to be older than the rest of the Northern Andes (Mora et al., 2010). Within the Central Andes, Saylor and Horton (2014) showed that the timing of uplift pulses may differ between regions, with current elevations in the northern part of the central Andean plateau as old as $16 \mathrm{Ma}$, and thus $\sim 6 \mathrm{Ma}$ older than other parts of the central Andean plateau. Such nonuniform spatial patterns of uplift have also been suggested for the Northern Andes (Hoorn et al., 1995). For the Southern Andes, Blisniuk et al. (2005) indicates that most of the uplift would have occurred by $16.5 \mathrm{Ma}$, earlier than most of the Central Andes, and several studies are in line with the idea of an Early Miocene uplift of the Southern Andes (e.g., Jordan et al., 2001; Encinas et al., 2013; Fosdick et al., 2013), but Late Miocene phases of uplift have also been reported for the northern Patagonian Andes (Ramos et al., 2014).

The Andes exerted an enormous influence on climate and hydrology at continental scale. The most conspicuous effect is the disruption of large-scale atmospheric circulation (Garreaud et al., 2009). Asymmetries in rainfall between western and eastern South America are influenced by the elevation and orientation of the Andes, with two dry regions, the Atacama and Peruvian coastal deserts on the western side of the Andes and the extratropical plains in southern Argentina on the eastern side of the Andes (Garreaud, 2009), strongly affected by a rain-shadow effect caused by the Andes (Stern and Blisniuk, 2002; Houston and Hartley, 2003; Smith and Evans, 2007), with well-documented consequences for vegetation (Troll, 1968). In the Southern Andes, precipitation on the western slope is caused by frontal systems moving eastward from the Pacific. The effect of these frontal systems is orographically enhanced by the Andes (Garreaud, 2009), with precipitation maxima around $47^{\circ} \mathrm{S}$ (Luebert and Pliscoff, 2006) and an increase of precipitation with elevation and distance from the Pacific Ocean on the western Andes (Stern and Blisniuk, 2002). On the eastern side of the Southern Andes, precipitation strongly decreases due to a rain-shadow effect. Paleobotanical evidence (Barreda and Palazzesi, 2007) tend to confirm the relationship between Andean uplift and onset of arid conditions over Patagonia during the Miocene if the time estimates of Blisniuk et al. (2005) are accepted. In the Central and Northern Andes the asymmetry between East and West is reversed. Aridity is maximal a few kilometers off the Pacific coast on the western side of the Andes, mostly due to the combined effects of the Pacific anticyclone, the Humboldt current and the rain-shadow effect of the Andes (Hartley, 2003; Houston and Hartley, 2003; Rutllant et al., 2003). The effect of the cold Humboldt current on aridity in western South America may have also been intensified or reinforced by Andean uplift (Sepulchre et al., 2009). No comparable paleobotanical evidence is available for the onset of aridity in the Peruvian and Atacama deserts, but phylogenetic studies in Atacama endemic taxa tend to indicate a rather recent (MiocenePliocene) origin of diversification of these lineages in response to aridity (e.g., Luebert and Wen, 2008; Dillon et al., 2009; Heibl and Renner, 2012), falling into the range of estimates for onset of present-day hyperaridity of the Atacama Desert (Alpers and Brimhall, 1988; Hartley, 2003; Hartley and Rice, 2005; Arancibia et al., 2006; Reich et al., 2009). These climatic changes exerted feedbacks on Andean uplift. While aridity on the western slope can be seen as a cause of uplift (Lamb and Davis, 2003), positive feedbacks between uplift and aridity are to be expected in the Central Andes. Conversely, in the Southern Andes uplift led to increases in precipitation in the western Andean side, so that negative feedback is to be expected (Blisniuk et al., 2005). Rainfall also tends to increase with elevation on the western side of the Central Andes, but rather due to the influence of the northeast summer monsoon over the Altiplano (Houston and Hartley, 2003). This summer monsoon is co-responsible for humid conditions on the eastern side of the continent at tropical and subtropical latitudes, the influence of which is prevented by the Andes on the western side (Garreaud et al., 2009).

Hydrological effects of the Andes are complex (Buytaert et al., 2009). One of the most important factors is related to the increase of precipitation with elevation, which makes the Andes one of the most important water sources on the continent and supports rivers, glaciers and ice fields (Houston, 2006; Garreaud, 2009), as well as sediment supply into the major water basins East and West of the Andes (e.g., Aalto et al., 2006; Hoorn et al., 2010). Drainage system formation requires topographic control. In particular, surface deformation and erosion required for drainage development has been documented to be coincident or posterior to the Andean uplift in the northern (Mora et al., 2010) and Central Andes (Hoke et al., 2007; Schildgen et al., 2009). The idea of a causal effect between Andean uplift and canyon formation has recently been challenged, arguing that surface uplift and canyon incision are temporally decoupled and putting forward the idea that climate change has been at least co-responsible for canyon formation in the Central Andes (Lease and Ehlers, 2013). This temporal decoupling between uplift and canyon formation is based on a divergent view of the timing Andean orogeny, as discussed above.

In this paper we discuss the available literature on dated and undated phylogenies of Andean lineages of vascular plants in the light of the various scenarios proposed for the timing of Andean uplift. We attempt to cover most of literature on vascular plant diversification related to the Andes, including some extra-Andean lineages whose diversification may have been influenced by the Andes. However, the number of lineages involved is potentially so high that it will exceed the capacity of the authors to finish this review before it becomes obsolete. Therefore, there is no intention 
to exhaustively revise all the literature or to cover all Andean plant groups.

\section{EFFECTS OF THE ANDES ON PLANT DIVERSIFICATION}

According to Simpson $(1975,1983)$, Luebert et al. (2009), Antonelli and Sanmartín (2011b), and Hoorn et al. (2013), effects of the Andes on plant diversification and evolution can be grouped into four major categories: (1) The Andes as source of new high-elevation habitats; (2) The Andes as a vicariant barrier, both on their eastern and western sides as well as internally; (3) The Andes as a North $\leftrightarrow$ South corridor; (4) The Andes as generator of new environmental conditions outside the Andes. It has to be emphasized, that these factors acted in dramatically different ways for different ecosystems: The western and eastern slopes are today disjunct habitats, their disjunction came about by the final stages of Andean orogeny, when the central Andean chains and plateaus reached their current elevations. Exchange since then has only been possible via long-distance dispersal. Conversely, high-Andean habitats naturally formed later, in the last stages of orogeny, and-depending on topography—nowadays form more or less coherent or disjunct regions, which underwent dramatic changes in extent and connectivity during the glaciations. Although these factors may certainly act in combination upon some lineages, we will try to analyse the phylogenetic literature considering each of these causal mechanisms separately.

\subsection{THE ANDES AS SOURCE OF NEW HIGH-ELEVATION HABITATS}

High plant diversity in the Andes is associated with high levels of endemism (Young et al., 2002). Simpson (1975) attempted to explain the high degree of diversity and endemism by colonization and diversification (extinction-speciation) processes that took place during the Pleistocene. This author postulated that Quaternary glaciations favored the expansion of Páramo environments, promoting floristic exchange across the region, followed by isolation during interglacial periods. This view is strongly influenced by the belief that the Andes reached their current elevation only just before the Pleistocene (Vuilleumier, 1971). After creation of high-Andean environments, vacant niches became available for colonization and speciation from lowland and midelevation elements, both from within and from outside the Neotropics (Simpson, 1983; Sklenár and Balslev, 2007). Results of phylogenetic studies tend to agree with this interpretation. This conclusion could automatically be extended to the Puna and Jalca habitats, which should have more or less parallel histories, but have been studied less extensively. Divergence time estimates for high- and mid-elevation Andean clades are summarized in Figure 2 .

\subsubsection{Northern Andes}

One of the best-known phylogenetic studies dealing with a species-rich high-Andean group was carried out on the genus Lupinus (Fabaceae; Hughes and Eastwood, 2006; Drummond et al., 2012). One of the centers of diversity of Lupinus (Figure 1D) are the northern and Central Andes with $\sim 85$ species, 81 of which represent a monophyletic group with most of its species growing above $3.000 \mathrm{~m}$. The authors estimate a crown node age for this clade to $\sim 2 \mathrm{Ma}$, suggesting a Pleistocene radiation. In addition, this radiation is interpreted as the result of ecological opportunity, which is supported by the exceptional life-form diversity observed in high-Andean Lupinus, and it is claimed that an island-like diversification process can be invoked, driven by the isolation of the high-elevation areas in the Andes and reinforced by the geographical extension of the Andean region. Similar results and interpretations had been proposed for Gentianella (Gentianaceae; von Hagen and Kadereit, 2001, Figure 1A), or with a more recent age of diversification $(<1 \mathrm{Ma}$ ) for Andean Halenia (Gentianaceae; von Hagen and Kadereit, 2003). High-Andean species in the genus Lepechinia (Lamiaceae) form a clade of ca. 30 species that may have started their divergence during the Early Pliocene ( 3 Ma; Drew and Sytsma, 2013). The latter authors explain this diversification by climatic changes and the simultaneous rise of the Andes, leading to an increased availability of open habitats favored by Lepechinia.

Similar crown node ages have been reported for the Páramo clade of the genus Hypericum (Hypericaceae), with diversification rates that are greater than in any other clade in Hypericum (Nürk et al., 2013). High diversification rates in the Páramos have also been suggested for the Andean genus Diplostephium (Asteraceae; Vargas and Madriñán, 2012). In this line, Páramo flora has been recently studied extensively by Madriñán et al. (2013) who analyzed diversification rates for over 15 of the most diverse Páramo plant groups, including Aragoa (Plantaginaceae), Arcytophyllum (Rubiaceae), Berberis (Berberidaceae), Calceolaria (Calceolariaceae), Draba (Brassicaceae, Figure 1E), Espeletiinae (Asteraceae), Festuca (Poaceae), Jamesonia (Pteridaceae), Lupinus (Fabaceae), Lysipomia (Campanulaceae), Oreobolus (Cyperaceae), Puya (Bromeliaceae), and Valeriana (Valerianaceae, Figure 1F). They found the highest diversification rates among biodiversity hotspots across the world in these groups. Since most of the speciation events detected in these lineages occurred during the Pleistocene, the authors suggest that these exceptional diversification rates may have been a consequence of range expansion and contraction of populations due to Quaternary climatic oscillations.

However, for the Páramo clade of Valerianaceae Bell and Donoghue (2005) and Madriñán et al. (2013) estimated older ages, ranging from $\sim 20$ to $\sim 5 \mathrm{Ma}$. Andean uplift has been suggested as a possible explanation for all these diversifications and similar scenarios are plausible for mid-elevation taxa.

Most of the diversity of the genus Vasconcellea (Caricaceae) is in the Northern Andes, with 18 out of its 20 species (Antunes Carvalho and Renner, 2012). Crown node age of Vasconcellea was dated to the Middle Miocene (ca. 14 Ma), originating in situ from a Central American ancestor, with a later secondary colonization of Central America (Antunes Carvalho and Renner, 2012). Andean orogeny has been invoked to explain the diversification of Vasconcellea. Two early diverging (Late Miocene, $\sim 8 \mathrm{Ma}$ ) species of Brunfelsia (Solanaceae) inhabit the Andean foothills and montane forests of the Northern Andes (Filipowicz and Renner, 2012). For the tribe Cinchoneae (Rubiaceae), Antonelli et al. (2009) suggested that diversification at midelevation habitats in the northern and Central Andes during the Middle and Late Miocene was favored by ecological adaptation to higher altitudes. New World Gesneriaceae have a center of 


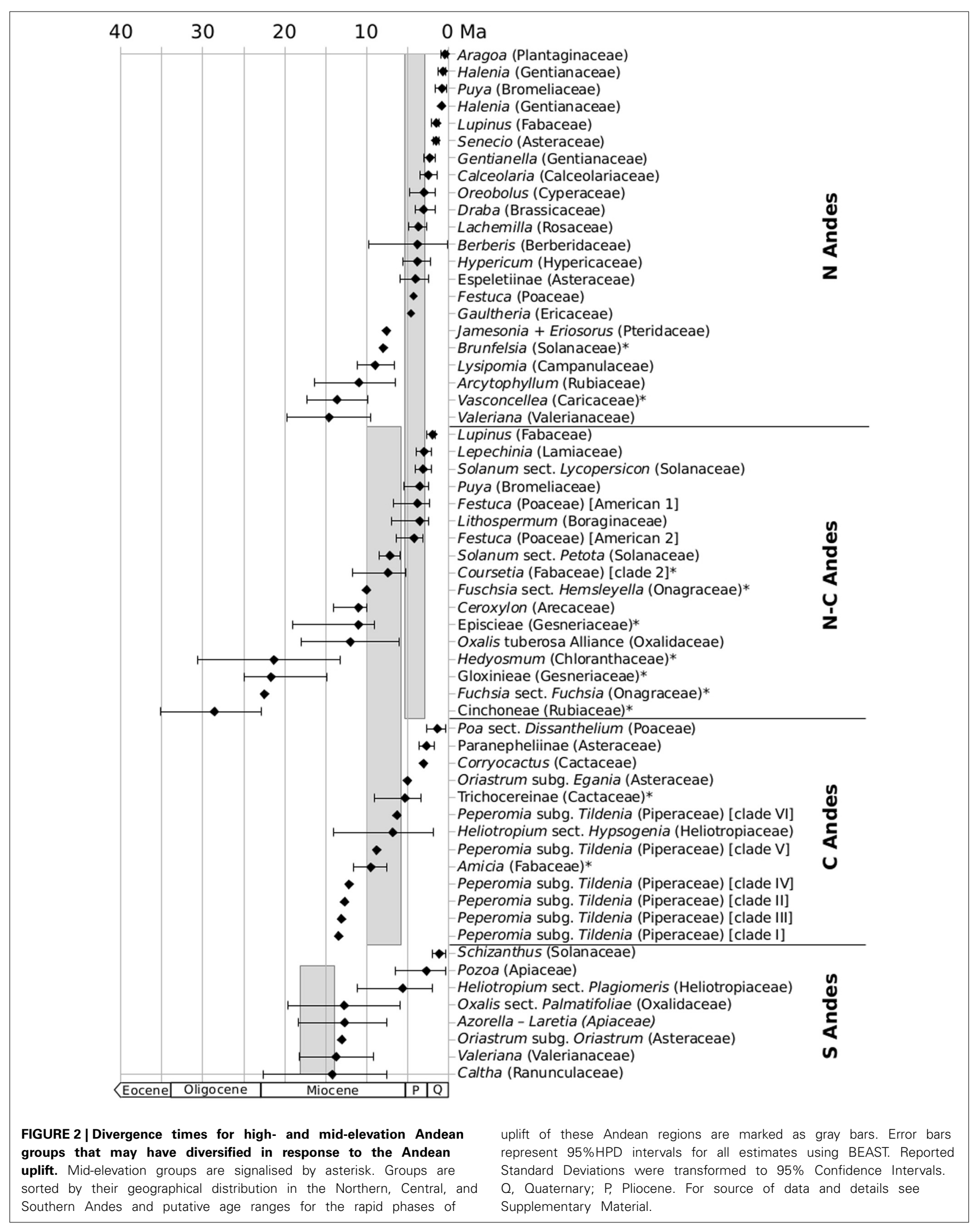


diversity in the Northern Andes and Perret et al. (2013) document at least two Andean radiations (in Gloxinieae and Episcieae). Gloxinieae originated in the Andes during the Early Miocene, but did not start their diversification until the Middle or Late Miocene. Andean diversification of Episcieae started during the Middle Miocene (ca. $10 \mathrm{Ma}$ ), coincident with a period of presumably rapid Andean uplift. According to Perret et al. (2013), the latter radiation accounts for more Andean species than any other clade of Gesneriaceae. Diversification of the genus Hedyosmum (Chloranthaceae) in the Northern Andes has been dated to ca. $10 \mathrm{Ma}$ (Antonelli and Sanmartín, 2011a), similar to the age reported for the Andean palm genus Ceroxylon (Arecaceae; Trénel et al., 2007).

\subsubsection{Central Andes}

In the genus Puya, an Andean radiation gave rise to $\sim 200$ species during the Late Miocene-Early Pliocene (Givnish et al., 2011) and this may have been favored by the evolution of CAM photosynthetic pathway in some species (Givnish et al., 2014) plus allopatric speciation driven by Pleistocene glacial cycles (Jabaily and Sytsma, 2013). Evolution of CAM photosynthetic pathway was also put forward as an explanation for the diversification of the genus Deuterocohnia (also Bromeliaceae) at various elevations in the Andes during the Late Miocene (Givnish et al., 2014). Andean uplift associated with the development of root tubers was proposed for the origin of the high-Andean Heliotropium sect. Hypsogenia (two species, Heliotropiaceae) in the Central Andes (Luebert et al., 2011a), whose diversification has been dated to ca. $5 \mathrm{Ma}$ (Luebert et al., 2011b). In Lithospermum (Boraginaceae), a genus with a center of diversity in the Central Andes (Weigend et al., 2010), Weigend et al. (2009) estimated a crown node age for the South American to ca. 3.5 Ma. In the highAndean Corryocactus (Cactaceae), Hernández-Hernández et al. (2014) estimated a Pliocene age for its diversification ( $3 \mathrm{Ma})$. Shifts in diversification rates were inferred for the subtribe Trichocereinae (Cacatceae), centered on the Central Andes, whose diversification started after $7 \mathrm{Ma}$, coincident with the Andean uplift in that region (Arakaki et al., 2011; Hernández-Hernández et al., 2014). However, according to the phylogeny presented by Schlumpberger and Renner (2012), many subsequent dispersal events between the Andes and eastern South America can be inferred in both directions. Taxonomic complexity and the lack of detailed dated phylogenies and biogeographical analyses in this group of Cactaceae make it difficult to provide an explanation for its diversification. Nonetheless, based on the distribution of its Andean taxa both in the inter-Andean valleys and at highelevation habitats (Anderson, 2005), it is likely that a combination of inner Andean vicariance and upward colonizations played a role in the divergence of this group with well over 100 extant species. The study of Schlumpberger and Renner (2012) suggests that pollinations syndromes are evolutionarily labile in this group. Therefore, repeated evolution of pollination syndromes may have contributed to reproductive isolation in recent speciation events. In Peperomia subg. Tildenia (Piperaceae), there are several central-Andean clades, all of which started their diversification after ca. $13 \mathrm{Ma}$, coincident with the onset of central Andean uplift (Symmank et al., 2011). Poa sect. Dissanthelium
(Poaceae), with a center of diversity in the Central Andes, forms a monophyletic group of 20 species (Refulio-Rodriguez et al., 2012) that diversified in the last ca. $1 \mathrm{Ma}$ (Hoffmann et al., 2013). In another central Andean example, Soejima et al. (2008) estimated that the stem node of Paranepheliinae, a high Andean plant group, to be around $13 \mathrm{Ma}$ old. However, the main diversification of the group did not occur until around $2 \mathrm{Ma}$. Hybridization may have played a role in the diversification of this group. Two genera of Paranepheliinae, Paranephelius (seven species) and Pseudoonoseris (three species), are distributed at higher (2500-4000 m) and lower elevations, respectively. They seem to be sister groups, which indicates that the group originated at lower elevations during the Miocene and one of the lineages, Paranephelius, later diversified at higher elevations. One of the odd endemic Central Andean groups is Laccopetalum + Krapfia, sister to subcosmopolitan Ranunculus (Ranunculaceae). Species of this clade are currently restricted to very high elevations ( $>3500 \mathrm{~m}$ ), but their divergence from Ranunculus is placed into the early Miocene (ca. $21 \mathrm{Ma}$ ), with a divergence of Laccopetalum and Krapfia placed at ca. $6 \mathrm{Ma}$ (Emadzade and Hörandl, 2011).

Polyploidization has often been associated with speciation in high-Andean environments. Polyploidy was suggested to be involved in the diversification of the Oxalis tuberosa Alliance (Oxalidaceae; Emshwiller and Doyle, 1998, 2002), with a center of diversity in the Central and Northern Andes (Emshwiller, 2002). The main diversification of this group was dated to be of Late Miocene age (Heibl and Renner, 2012). In monophyletic and widespread American Solanum sect. Petota (Solanaceae), a high concentration of polyploid species relative to total number of species was reported for the Northern Andes, while diploid species predominate in the Central Andes (Hijmans et al., 2007). This possibly originally South American group (Simon et al., 2011), started its diversification about 7 Ma (Särkinen et al., 2013). Polyploidization was also suggested as a driver of diversification for the central and northern Andean genus Polylepis (Rosaceae; Schmidt-Lebuhn et al., 2010), but divergence times estimates are not provided. The genus Tarasa (incl. Nototriche; Malvaceae), which includes several high-elevation species of the Central Andes, also comprises some polyploids (Tate et al., 2005). While diploid species predominate in low-elevation habitats, most polyploids are high-Andean. In Tarasa, allopolyploidization and shifts to autogamous breeding systems (both of which occurred several times) may have enabled species to colonize high Andean environments (Tate and Simpson, 2003). The process is suggested to be relatively recent (Quaternary; Tate and Simpson, 2004), but molecular dating is not available.

\subsubsection{Southern Andes}

In the Southern Andes, the genus Schizanthus (Solanaceae) possesses two high Andean species that have been resolved as sister to each other and are estimated to have diverged ca. $1 \mathrm{Ma}$ (Särkinen et al., 2013), probably associated with a shift to hummingbird pollination (Pérez et al., 2006). The divergence time estimates for Valeriana (Valerianaceae) by Bell et al. (2012) are considerably higher $(\sim 13 \mathrm{Ma})$. These authors suggest that Valeriana originated in the Southern Andes before final uplift, and that the group diversified into the higher elevations from 
either sides of the Andes once the Southern Andes reached their current elevation (see above). For the southern Andean Palmatifoliae clade of Oxalis, Heibl and Renner (2012) suggested an origin in alpine habitats and a start of diversification during the Middle Miocene $(\sim 19 \mathrm{Ma})$. The same authors estimate a more recent origin (Late Miocene to Pliocene) of alpine species of the Alpinae clade, which entered the alpine habitats several times with no subsequent radiations in high-elevation environments. The southern Andean representatives of the genus Caltha (Ranunculaceae) form two independent lineages, both with Late Miocene crown node ages (Cheng and Xie, 2014). Similar ages ( $\sim 5 \mathrm{Ma})$ were proposed for southern Andean Heliotropium sect. Plagiomeris (Heliotropiaceae; Luebert et al., 2011b). This is the only Neotropical section of the genus Heliotropium with ephemeral annual life form, which is associated with the relative aridity of their habitats (Luebert et al., 2011a). Palazzesi et al. (2012) found a divergence of the major southern/central Andean lineages of Geraniales in the Oligocene and Early Miocene, with actual species divergence only in the Pleistocene and argue for an early south-temperate diversification of the order with much later speciation in an Andean context. The subantarctic, Andean species of Nothofagus s.str. (Nothofagaceae; see Heenan and Smissen, 2013) diverged around $20 \mathrm{Ma}$ (scenario 1 of Sauquet et al., 2012). Unfortunately, the phylogeny of Nothofagus in this part of the tree is not yet well-resolved (Sauquet et al., 2012; Heenan and Smissen, 2013). Also in the Southern Andes, the diversification of the genus Oriastrum (Asteraceae; nomenclature following Davies, 2010) in high-elevation environments contrasts between southern and central Andean clades (Hershkovitz et al., 2006): while the southern Andean centered subgenus Oriastrum may have diversified about $13 \mathrm{Ma}$, crown node age of the central Andean subgenus Egania was estimated to ca. $5 \mathrm{Ma}$, possibly correlated to the differences in the timing of the Andean uplift between the central and the Southern Andes as discussed above.

\subsection{THE ANDES AS A VICARIANT BARRIER}

\subsubsection{East-West Andean vicariance}

Disjunct patterns in plants groups inhabiting both sides of the Andes have long been noticed in the literature. One of the earliest authors mentioning this pattern was Kuntze (1895) and it has since been interpreted by Neotropical biogeographers as a sign of the effects of the Andean uplift and the subsequent development of aridity in South America (e.g., Schmithüsen, 1956; Smith, 1962; Landrum, 1981; Moreira-Muñoz, 2011).

There are some recent phylogenetic studies documenting the age of disjunct clades inhabiting both the eastern and the western versant of the Andes but not the intervening area. Marquínez et al. (2009) report a mid-Miocene age ( 13-16 Ma) for the crown node of a disjunct South American clade of Drimys (Winteraceae). The authors suggest that speciation in the genus Drimys in South America coincides with Central Andean uplift. In Fuchsia sect. Quelusia (Onagraceae) Berry et al. (2004) report a similar age for the disjunction between F. magellanica, practically restricted the south-western Andes, and the other members of the section, distributed in southern Brazil (Berry, 1989), which would thus indicate the onset of aridity in SE South America around that time. Chacón et al. (2012) also report
mid-Miocene ages for the separation of the Brazilian clade of Alstroemeria (Alstroemeriaceae) from the western clades. Three species of Brunfelsia inhabit the Pacific coast of South America and they diverged from their disjunct sister species in Venezuela about $7 \mathrm{Ma}$, coincident with the peak of the Colombian Andean uplift according to Filipowicz and Renner (2012). In the genus Phytelephas (Arecaceae), distributed on the eastern and western slopes of the Central and Northern Andes, crown node ages were estimated to be of Middle to Late Miocene age (Trénel et al., 2007). Finally, for the genus Monttea (Plantaginaceae), disjunctly distributed on the arid zones of both sides of the Andes, the split between eastern and western species was estimated to be of Late Micocene age ( 5-10 Ma; Baranzelli et al., 2014), coinciding with the Andean uplift according to the rapid model. Figure 3A illustrates divergence time estimates for all vicariant groups mentioned above.

Monophyly of several other disjunct plant groups has been documented in recent phylogenetic studies, but dates have not been proposed. For example, the genus Myrceugenia (Myrtaceae) has long been considered a typical example of a South American disjunction mediated by Andes uplift (Landrum, 1981). MurilloA. et al. (2012) suggest that the disjunction of Myrceugenia may have taken place during the Early Miocene. Another example are the sister genera Balsamocarpon and Zuccagnia (Fabaceae). The former is distributed in the southern portion of the Atacama Desert, on the western side of the Andes, while the latter has a distribution in the Chaco region on the eastern side of the Andes (Ulibarri, 2005). These genera form a monophyletic group together with Hoffmannseggia and Stenodrepanum (Nores et al., 2012). These authors suggest that the Andes acted as a barrier in the divergence of Balsamocarpon and Zuccagnia, followed by diversification and long-distance dispersal events in Hoffmannseggia. Bulnesia subg. Bulnesia (Zygophyllaceae) is a monophyletic group (Comas et al., 1998) with a similar distribution pattern to Balsamocarpon/Zuccagnia on both sides of the Andes. Similarly, Suaeda foliosa (Amaranthaceae) is distributed in the Atacama and Peruvian deserts on the western side of the Andes and has been shown to be sister to S. divaricata from the Chaco region (Schütze et al., 2003). Davis and Anderson (2010) showed the monophyly of the genera Dinemandra and Dinemagonum (Malpighiaceae), both from north central Chile on the western slope of the Andes, and the genus Ptilochaeta from the Chaco and Paraná regions on the eastern side. Mexican Lasiocarpus is nested in Ptilochaeta and Anderson (2013) argues that Lasiocarpus represents a secondary colonization of this group from South America to Mexico.

\subsubsection{Inner Andean vicariance}

The inner-Andean valleys also represent habitats that were isolated by Andean orogeny and should thus promote vicariant speciation. This idea has been suggested in several papers (e.g., Struwe et al., 2009).

One example is Heliotropium sect. Heliothamnus, with a center of diversity in the inner-Andean valleys of Ecuador and Peru and for which a Miocene age of its crown node was proposed (Luebert et al., 2011b). Pennington et al. (2010) studied different populations of the species Cyathostegia mathewsii (Fabaceae), distributed 


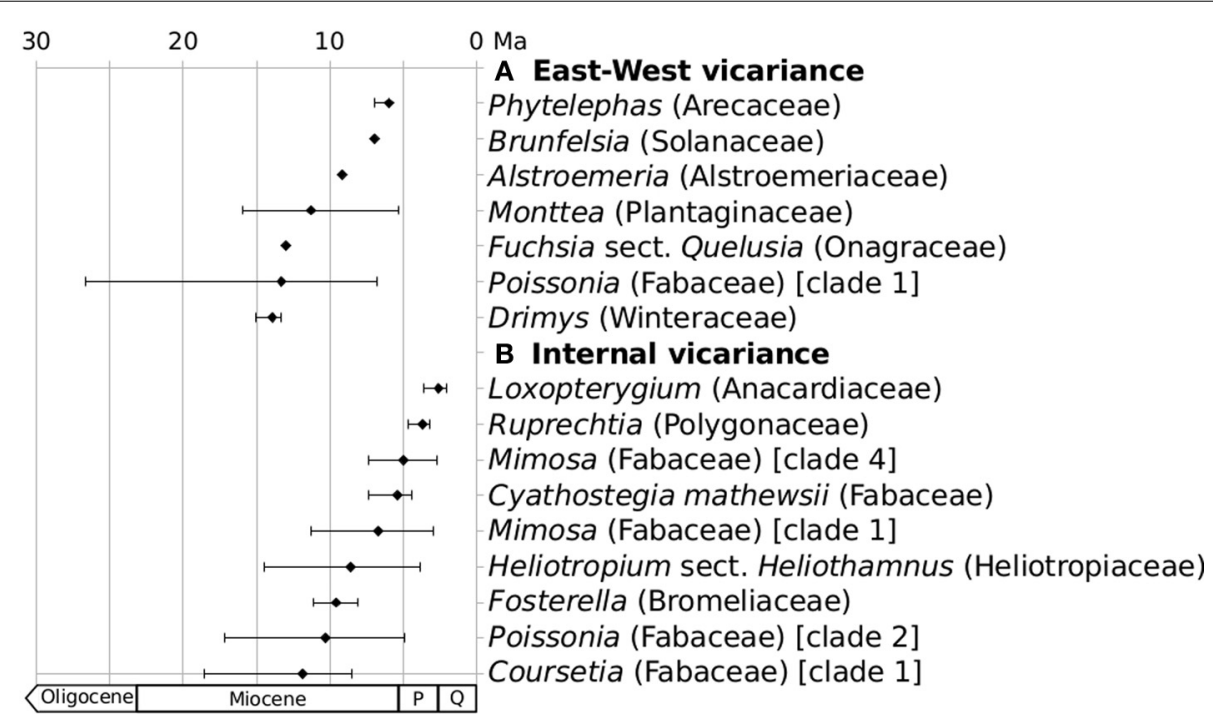

FIGURE 3 | Divergence times for plant groups that may have diversified in response to the Andean uplift. (A) Groups disjunct on the western and eastern side of the Andes; (B) Groups distributed in the inner Andean valleys. Error bars represent 95\% HPD intervals for all estimates using BEAST. Reported Standard Deviations were transformed to 95\% Confidence Intervals. Q, Quaternary; P, Pliocene. For source of data and details see Supplementary Material. disjunctly in inner-Andean valleys from southern Ecuador to southern Peru. The authors found a strong phylogenetic signal in the distribution of the populations and identified four geographically well-defined clades. They estimated the crown-node age of $C$. mathewsii to be Late Miocene/Early Pliocene (5.4 \pm $1 \mathrm{Ma}$ ), which they associate with the vicariant effect of valley formations just before the origin of $C$. mathewsii. The crown node of the genus Poissonia (Fabaceae) was dated to the Early Miocene ( $20 \mathrm{Ma}$; Pennington et al., 2004; Särkinen et al., 2011). This genus is composed of two well-supported clades of seasonally dry tropical forests (SDTF) species, one inhabiting both sides of the Andes (Chaco and Peruvian Desert) and the other distributed along the Central Andes (Pennington et al., 2004; Särkinen et al., 2011). Both clades started their diversification around $10 \mathrm{Ma}$ (Särkinen et al., 2011). The northern Andean species of Ruprechtia (Polygonaceae), also from SDTF, diversified during the Early Pliocene (clade C; Pennington et al., 2004). An even more recent diversification was suggested for the northern and central Andean SDTF species of Loxopterygium (Anacardiaceae), which was dated to Late Pliocene age (clade B; Pennington et al., 2004). Other examples are provided by Särkinen et al. (2011) for several Fabaceae lineages from Andean SDTF. These authors found that the crown node ages of the lineages from the SDTF range from ca. 19 to $4 \mathrm{Ma}$, suggesting that isolation of SDTF fragments in the Andes dates back to the Early Miocene and has persisted since, which they regard as in agreement with the "rapid rise" model described above. In the Andean genus Fosterella (Bromeliaceae), allopatric speciation associated with the Andean uplift was invoked to explain the diversification of this genus, whose origin was dated to Middle Miocene age (Wagner et al., 2013). Outside the Andes (SDTF and Yungas), Fosterella has some species distributed in azonal rock outcrops of the Brazilian highlands, lowlands of central Amazonia and Central America; the latter three areas were reached in different and recent colonization events after the Andean diversification of the group (Wagner et al., 2013). Figure 3B summarizes divergence time estimates for all these inner-Andean clades.

\subsection{THE ANDES AS A CORRIDOR}

Floristic and paleoecological studies suggest that the Andes acted as a dispersal corridor, overcoming dispersal barriers such as the most arid zone of the Atacama Desert or the low-lying AmotapeHuancabamba zone (e.g., van der Hammen and Cleef, 1983; Moreno et al., 1994; Weigend, 2002; Linares-Palomino et al., 2003; Pinto and Luebert, 2009; Schwarzer et al., 2010). Andean NorthSouth exchanges may have been favored by Quaternary climatic oscillations (van der Hammen, 1974; Moreno et al., 1994; Dillon et al., 1995). This may not only explain the distribution of several widely distributed plant groups of the Andes. Phylogenetic studies in the recent decades have contributed to clarify this question.

Doan (2003) proposed a general south-to-north diversification patterns for plants and animals based on the earlier uplift of the Southern Andes. This theory has found support for a range of plant groups. The genera Azorella (p.p., Figure 1C), Laretia and Mulinum (p.p.) (Apiaceae) form a well-supported clade distributed from Costa Rica to Patagonia along the Andes. Its geographical origin was inferred for the southern part of its distribution range, from which it migrated northwards since about $12 \mathrm{Ma}$ (Nicolas and Plunkett, 2012, 2014). These authors suggest that this group colonized the Central and Northern Andes after the Mid-Miocene climatic optimum (5-17 Ma), when the global climate became cooler (Zachos et al., 2001) and the Andes reached their current elevation (see above). In the genus Oreobolus (Cyperaceae), there is a South American clade with a wide Andean distribution; this clade may also have originated in the Southern Andes and migrated northwards during the Early Pliocene ( $4 \mathrm{Ma}$; Chacón et al., 2006). In the genus Perezia (Asteraceae, Figure 1B), Simpson et al. (2009) suggest that 
the genus colonized high-elevation habitats from low-elevation ancestors in the Southern Andes and subsequently migrated northwards along the Andes to eventually diversify in the Central Andes. An essentially parallel hypothesis is provided by Meudt and Simpson (2006) based on data on Ourisia (Plantaginaceae), which clearly originated in the Southern Andes and subsequently dispersed to the Central and Northern Andes, where further speciation took place. In Chuquiraga (Asteraceae), distributed from Patagonia to Venezuela along the Andes (Ezcurra, 2002; Gruenstaeudl et al., 2009), a southern origin was inferred (Gruenstaeudl et al., 2009). Unfortunately, no time framework is provided for Perezia or Chuquiraga. Extensive northward migrations from south-temperate regions are also documented by a combination of fossils and a dated phylogeny for several lineages in Geraniales (Palazzesi et al., 2012).

Antonelli et al. (2009) suggested a considerable importance of the Western Andean Portal (WAP) in Andean biogeography. The WAP was an East-West corridor located around the present Ecuadorian/Peruvian border (i.e., the AmotapeHuancabamba zone) that enabled Pacific marine incursions into the Amazonian basin until the Middle Miocene, when the marine incursions ceased due to Andean uplift (Hoorn, 1993). Biogeographical reconstructions in the genera Cinchona and Ladenbergia (Rubiaceae) suggest multiple migrations from the northern to the Central Andes around 12-10 Ma, attributed to the closing of the WAP (Antonelli et al., 2009). High Andeanspecies of the genus Puya (Bromeliaceae) are concentrated in the Northern Andes, a diversity reached after this area was colonized by high-elevation, central-Andean ancestors that crossed the WAP (Jabaily and Sytsma, 2013) around 6-4 Ma (Givnish et al., 2011, 2014). A smilar pattern was proposed for Solanum sect. Petota, which diversified in the Northern Andes from central Andean ancestors (Simon et al., 2011) during the Late Miocene (Särkinen et al., 2013). The opposite route was inferred for the genus Hedyosmum (Chloranthaceae), which colonized the central Andes from northern Andean ancestors several times after Andean uplift (Antonelli and Sanmartín, 2011a). For the genus Festuca (Poaceae), Inda et al. (2008) suggested that Patagonian species originated from North America through a North to South migratory route along the Andes during the Late Miocene - Early Pliocene (10-3.8 Ma). A similar dispersal pattern was reported in Cleome (Cleomaceae), with a well-supported clade (incl. Podandrogyne) originating in the Northern Andes during the Late Miocene and a subsequent dispersal into and radiation in the Central Andes (Feodorova et al., 2010).

In a study of Macrocarpaea (Gentianaceae), a genus of montane forest species, an Andean origin around the AmotapeHuancabamba zone, with radiations in both north- and southwards directions was postulated (Struwe et al., 2009). These radiations correspond to two well-supported subclades distributed to the South and to the North of the Amotape cross, within which allopatric speciation between adjacent zones of the same mountain range were hypothesized (Struwe et al., 2009). Migrations from the Southern Andes through the AmotapeHuancabamba zone into the Northern Andes suggest that the Amotape-Huancabamba zone was not a dispersal barrier for lineages of mid-elevations. Although these authors did not provide divergence time estimates, they suggest that these diversification events occurred after the major phases of Andean uplift since Miocene times.

In the genus Nolana (Solanaceae), with a center of diversity in the Atacama and Peruvian Deserts, several events of dispersal between both these deserts were suggested to have taken place along the Andes (Dillon et al., 2009). These events may have taken place during the Late Pliocene and Pleistocene, as shown by different molecular dating analyses (Dillon et al., 2009; Särkinen et al., 2013). Andean exchanges may have been followed by diversification in the coastal range. A very similar pattern of distribution and dispersal can be observed in Malesherbia sect. Malesherbia (Malesherbiaceae), where Gengler-Nowak (2002) argued for Pleistocene or even Holocene floristic exchanges. Phylogenetic and biogeographical analyses of the allied genera Polyachyrus, Moscharia and Oxyphyllum (Asteraceae; Katinas and Crisci, 2000; Katinas et al., 2008; Luebert et al., 2009) would also suggest this pattern, with Pleistocene southwards colonizations from the Central Andes to central Chile, but no dating analysis is available for these groups.

\subsection{THE ANDES AS PROMOTERS OF DIVERSIFICATION OUTSIDE THE ANDES}

Several studies have highlighted the possible effects of Andean uplift on the diversification of lineages outside the Andean range. The idea that Andean uplift is important in the diversification of Neotropical lowland plant taxa has been mentioned in the literature at least since Gentry (1982) and Kubitzki (1989).

Rapid diversification in the genus Inga (Fabaceae) is a classical example. This genus is particularly diverse on the eastern Andean foothills and in the Amazonian basin. Rapid diversification of Inga in this area was suggested to have been promoted by the later phases of Andean orogeny (Richardson et al., 2001). In the mostly extra-Andean tribe Bignonieae (Bignoniaceae), Lohmann et al. (2013) suggested that the Andean orogeny played an important role in the diversification of some lineages in the Amazon basin and eastern South America. In the tribe Cinchoneae (Rubiaceae), the Andean orogeny was suggested to have played a role in diversification in lowland Amazonia (Antonelli et al., 2009). These authors argue that the connection between the Andean uplift and the demise of Lake Pebas during the Late Miocene is consistent with colonizations by eastern Andean ancestors into lowland Amazonia from the Late Miocene onwards. Miocene diversification of the rain forest genus Renealmia (Zingiberaceae) also gives support to the idea that its diversification was influenced by the rise of the Andes (Särkinen et al., 2007), similar to what was proposed to several genera of the Annonaceae with Miocene diversifications (Pirie et al., 2006)

Diversification of the tribe Protieae (Burseraceae) in the western Amazon was suggested to be associated with the creation of new edaphic habitats during the uplift of the Andes (Fine et al., 2005). However, divergence times for this group ( $\sim 40 \mathrm{Ma}$; Becerra et al., 2012) seem to predate Andean uplift. In the family Chrysobalanaceae, the lowland Amazon genera Hirtella and Couepia diversified during the Middle Miocene ( $\sim 12 \mathrm{Ma}$; Bardon et al., 2013), but their diversification was probably not causally linked to Andean uplift. In fact Amazonian lowland taxa in general are a mixture of old and young lineages, with ages ranging from 40 to $5.6 \mathrm{Ma}$ in the analysis of Hoorn et al. (2010) 
and the data currently available do not paint a clear picture as to the overall importance of Andean uplift for Amazonian diversifications.

Luebert and Wen (2008) and Luebert et al. (2011b) proposed the Middle Miocene as the minimum age for the origin of Heliotropium sect. Cochranea (Heliotropiaceae). The diversification of this group in the Atacama Desert during the Pliocene, isolated on the western slope of the Andes, was probably facilitated by Andean uplift and the subsequent development of aridity (Sepulchre et al., 2009). This scenario was also suggested for the origin of monotypic Gypothamnium (Asteraceae) in the Atacama Desert (Luebert et al., 2009) and for Plectocephalus in South America (Asteraceae; Susanna et al., 2011). On the south-eastern side of the Andes, the onset of diversification of Heliotropium sect. Heliotrophytum around $8.5 \mathrm{Ma}$ has also been related to increasing aridity as a consequence of Andean orogeny (Luebert et al., 2011b).

\subsection{BIOGEOGRAPHICAL RELATIONSHIPS OF THE ANDEAN FLORA}

Many of the aforementioned phylogenetic studies included lineages that also occur outside of the Andes and therefore provide insights into the biogeographical relationships between the Andes and other regions.

One of the most obvious patterns is the connection between Central America, and especially the central American Cordillera, and the Andes. Floristic interchange in both directions is documented in Gesneriaceae (Perret et al., 2013). In Gloxinieae a colonization event Andes to Central America occurred during the early Miocene and at least one more after the Late Miocene. Episcieae dispersed from Central America to the Andes several times from the Late Miocene onwards. The closing of the Panama Isthmus may have facilitated northward dispersals of South American lowland lineages into Central America, as inferred for Joosia and Isertia (Rubiaceae) (Antonelli et al., 2009). The same route and time frame was suggested for Pitcairnia and Tillandsia (Bromeliaceae; Givnish et al., 2014), which reached Central America from Andean ancestors independently around $5 \mathrm{Ma}$ (Givnish et al., 2011). In Peperomia subg. Tildenia, Central American taxa originated from central Andean ancestors around $15 \mathrm{Ma}$ (Symmank et al., 2011). These authors suggest a northern Andean track and subsequent extinction of the group in the Northern Andes, since the current northern limit of Peperomia subg. Tildenia in the Andes is around the AmotapeHuancabamba zone. The separation of Central American and Andean lineages in Ruprechtia (Polygonaceae) occurred ca. $6 \mathrm{Ma}$, but their respective diversifications did not start until 4-3 Ma (Pennington et al., 2004). All these time estimates indicate a dispersal across the Panama Isthmus before it closed ca. 3.5 Ma. This has also been suggested for Inga (Richardson et al., 2001). On the other hand, Coursetia (Fabaceae) colonized the Andes from Central America before its diversification started ca. $7 \mathrm{Ma}$ (Pennington et al., 2004). Costus (Costaceae) dispersed from Central America into the Andean region between ca. 1-6 Ma (Kay et al., 2005). In Halenia, the colonization of the South American Andes from Central America occurred more recently ( $\sim 1 \mathrm{Ma})$, according to the estimates of von Hagen and Kadereit (2003). Similar timing and direction were estimated for Lupinus by Drummond (2008). Overall, these estimates would be in agreement with the ideas of Simpson (1983), who argued that colonizations of the Andean flora by Nearctic elements occurred gradually since the Middle Miocene, and the closing of the Panama gap had little effect on it. In the case of alpine Lupinus and Halenia, dispersal must have been from mountain range to mountain range, and the presence or absence of the Isthmus can not conceivably have had an effect-the taxa can not have migrated via the lowland Daríen, whether covered by water or not. A generally limited importance of the Panama Isthmus is supported by various dated molecular phylogenies showing dispersal across the region older than the closing of the Panama Isthmus (Cody et al., 2010). However, as pointed out by Antunes Carvalho and Renner (2012), the colonization of South America by Caricaceae during the Early Miocene may have also been favored by a first closing of the Panama Isthmus ca. $24 \mathrm{Ma}$ (Farris et al., 2011), an earlier date than generally accepted.

Relationships between the northern and the Central Andes and the Brazilian highlands have been suggested for Tibouchina (Melastomataceae; Michelangeli et al., 2013), a connection also retrieved in phylogenetic studies on Elapghoglossum (Dryopteridaceae; Vasco et al., 2009), Sinningia (Gesneriaceae; Perret et al., 2006), Macrocarpaea (Gesneriaceae; Struwe et al., 2009), and Bromelioideae (Bromeliaceae; Givnish et al., 2014). The latter is the only dated dispersal scenario available ( $\sim 8 \mathrm{Ma}$; Givnish et al., 2011). Ecotopical similarity rather than geographical proximity may have played a role in the origin an floristic connections of those regions (Simpson, 1983). A similar rationale must necessarily explain the relationships between the Andes and the Guiana Shield, demonstrated for taxa such as Chaetolepis (Melastomataceae; Michelangeli et al., 2013), since they were never connected.

In a recent review, Luebert (2011) showed direct relationships between the Atacama Desert and the Central and Southern Andes in many genera with phylogenetic studies. Among the groups with relationships between the Central Andes and the Atacama Desert are Bomarea (Alstroemeriaceae), Cleome (Cleomaceae), Croton (Euphorbiaceae), Eremocharis (Apiaceae), Gypothamnium (Asteraceae), Krameria (Krameriaceae), Malesherbia sect. Malesherbia (Malesherbiaceae), Nasa (Loasaceae), Oxalis (Oxalidaceae), Oziroë (Asparagaceae), Prosopis ser. Cavernicarpae (Fabaceae), Solanum sect. Lycopersicon (Solanaceae), and Tarasa (Malvaceae), Vasconcellea (Caricaceae). Among the groups with relationships between the Atacama Desert and the Southern Andes are Asteriscium (Apiaceae), Chaetanthera (Asteraceae), Conanthera (Tecophilaeaceae) Montiopsis subg. Montiopsis (Montiaceae), Oxyphyllum (Asteraceae), Schizanthus (Solanaceae), Schizopetalon (Brassicaceae), Tropaeolum sect. Chilensia (Tropaeolaceae) (see references in Luebert, 2011). However, only few of them have been dated at the crown node of that relationship: Bomarea ( 5 Ma; Chacón et al., 2012), Asteriscium and Eremocharis (both $\sim 11 \mathrm{Ma}$; Nicolas and Plunkett, 2014), Oxalis ( 20 Ma; Heibl and Renner, 2012), Prosopis ( $1 \mathrm{Ma}$; Catalano et al., 2008), Solanum sect. Lycopersicon ( 2 Ma; Särkinen et al., 2013), Vasconcellea ( $10 \mathrm{Ma}$; Antunes Carvalho and Renner, 2012), Alstroemeria ( $18 \mathrm{Ma}$; Chacón et al., 2012), Chaetanthera ( 10 Ma; Hershkovitz et al., 
2006), Schizanthus ( 24 Ma; Särkinen et al., 2013). Floristic interchange between the Andes and the Atacama Desert has therefore been taking place continuously since Miocene times.

Surprisingly, fewer studies have shown the connection between the Andes and the immediately adjacent areas of eastern South America (incl. Amazon basin). Examples can be found in Brunfelsia, which made its way from eastern South America into the Andes around ca. $10 \mathrm{Ma}$ (Filipowicz and Renner, 2012), and the tribe Cinchoneae, whose Amazonian representatives originated from Andean ancestors during the late Miocene (Antonelli et al., 2009). Conversely, an eastern South American origin for Andean taxa in Chuquiraga for Andean taxa was inferred by Gruenstaeudl et al. (2009). Simpson et al. (2009) suggest that the geographical origin of the Andean lineages in Perezia is in the lowlands of Patagonia. Finally, in Oxalis subg. Trifidus, distributed in the Altiplano and temperate Chile, Heibl and Renner (2012) estimated a Middle Miocene split between its two component species.

Direct relationships between the Andean region and North America can be inferred for Urtica (Farag et al., 2013; Henning et al., 2014). American Urtica gracilis can be shown to be sister to an Australasian clade, U. gracilis then splits up into temperate North American subsp. gracilis as sister to the remaining subspecies, and western North American subsp. holosericea in turn sister to three subspecies distributed in Mexico/Guatemala, Peru and Chile/Argentina, respectively, with at likely two dispersal events from North America into South America along the American Cordillera. Conversely, the other group in American Urtica is sister to a Macaronesian clade, but also seems to have had at least two dispersal events between South and Central America, with a minor diversification in Mexico and a major diversification in the Andes. Timing has not been investigated for Urtica. On the other hand, colonization from North America to the northern Andes by Festuca took place ca. 4 Ma (Inda et al., 2008). The same biogeographical connection but more recent origin was suggested for Gentianella (von Hagen and Kadereit, 2001). Weigend et al. (2010) show that Lithospermum arrived from Southern North America initially to the Central Andes, and then migrated northwards and diversified in the Amotape-Huancabamba zone. According to Bell and Donoghue (2005), "Valerianaceae arrived in South America, most likely via long-distance dispersal. . .when the northwestern Andes were not at their current elevations." Dispersal from the north-temperate zone and especially the North American Cordillera into the Andes and subsequent diversification seems to be a fairly common pattern, although few detailed phylogenies are available. A clear Andes-North America direction was shown for the bulb-bearing Oxalis (Gardner et al., 2012). The dispersal of that group into North America may have occurred after its Middle Miocene origin (Heibl and Renner, 2012) by long distance dispersal.

More geographically distant relationships between the Andean Prumnopitys (Podocarpaceae) and its close relatives in Oceania (Knopf et al., 2012) date back to the Paleocene (Biffin et al., 2011), while in Nothofagus s. str. this separation seems to be more recent ( $\sim 2$ Ma, Middle Eocene; Sauquet et al., 2012). In Cunoniaceae, Bradford (2002) showed phylogenetic relationships between Andean Weinmannia, and W. tinctoria from the Mascarenes.
Since the position of $W$. trichosperma, from southern South American temperate forests, was resolved as sister to the tropical Andes-Mascarene clade, this author argued that exchanges between tropical America and the Indian Ocean occurred more recently than between temperate and tropical America. Although Bradford (2002) indicated that these results await confirmation, no study has challenged them so far. The diversification of Weinmannia occurred during Oligocene-Miocene transition (Heibl and Renner, 2012).

\section{DISCUSSION}

The exact timing and process of Andean uplift has been repeatedly invoked to explain Neotropical diversifications in plants, shaping the diversity of both Andean and extra-Andean groups (see reviews in Hoorn et al., 2010; Graham, 2011a; Särkinen et al., 2011; Madriñán et al., 2013). When the available evidence is analyzed, we only find partial support for that explanation. There is a trend in high-Andean lineages to be of more recent origin in the northern than in the Central Andes and in the central than in the Southern Andes (Figure 2), which agrees with the assumption that the Andean uplift progressed from South to North (see above). Plant groups inhabiting mid-elevation environments (such as Brunfelsia, Fuchsia, Fabaceae, Generiaceae, Hedyosmum, Oxalis tuberosa Alliance, Rubiaceae, Vasconcellea, see Figure 2) also tend to be older than high-Andean groups, which also agrees with progression of uplift. These trends are fairly stable and independent of the conflicting views on the exact timing of Andean uplift. However, these trends do not fit all studied plant groups. Some high-Andean lineages (Valeriana, several groups in Geraniales) are older than the presumed timing of the Andean uplift, while most are younger, especially in the Northern Andes (Figure 2).

For the latter, ecological opportunities to colonize highAndean environments may have differed between lineages, so that the speed of the diversification of life histories or other adaptive traits necessary to survive in extreme environments are lineage-specific. This may be the reason for a delayed evolutionary response in some lineages, explaining the evident lag times in diversification with respect to the formation of highelevation habitats. However, such an explanation lacks power, since this can be argued for any young group whose diversification started after the uplift of the Andes regardless of cause-effect links. Moreover, Late Miocene increases in Andean uplift rate coincides with a global cooling trend (Zachos et al., 2001, 2008), which can also be seen as a possible trigger of plant diversifications. Regarding the role of the Andes as vicariant barrier, the available data tend to be more consistent with the timing of the Andean orogeny. The separation of western South American Drimys $(\sim 14 \mathrm{Ma})$ and Fuchsia $(\sim 13 \mathrm{Ma})$ are consistent with the uplift times proposed for the Southern Andes (Figure 3). Groups distributed West and East of the Central and Northern Andes are younger ( $\sim 11-7 \mathrm{Ma})$ with the exception of Poissonia ( $\sim 13 \mathrm{Ma})$. A narrower range of ages $(\sim 12-3 \mathrm{Ma})$ is shown for putatively vicariant lineages distributed in the inner-Andean valleys (Figure 3). All groups for which the Andes have likely acted as a corridor for latitudinal dispersal diversified after the Andes reached their present elevation $(\sim 3-5 \mathrm{Ma}$, see Figure 3). An alternative 
explanation for younger lineages is proposed by Rull (2011a,b), partially in response to the general assumption that Andean uplift has driven Neotropical biotic diversification. This author argues that Pleistocene climatic fluctuations are at least co-responsible of present Neotropical diversity, since most speciation events occurred during this period, which fits the data available so far. This explanation, however, has the same inherent problems of power mentioned above. Moreover, current lineage diversity is always overestimated in phylogenetic studies compared to historical diversity, because newer lineages have had less time to go extinct than ancient lineages (Harvey et al., 1994). In this line, Hoorn et al. (2011) argued that crown node ages of clades "lead to more robust age estimation of deeper nodes even when many species are missing." However, disentangling the relative effects of different events that overlap in time may prove impossible using dated phylogenies (Pennington and Dick, 2010).

Older-than-uplift lineages also require an explanation. One possibility would be accepting an older origin of the high-Andes as suggested by Ehlers and Poulsen (2009). This would imply that most of the studied groups diversified with considerable lag times with respect to Andean uplift. On the other hand, these lineages could have initially diversified at lower elevations before the Andean uplift, with later colonization of the high elevation environments as they were forming. Since the global climates during the Middle Miocene were considerably warmer (the MidMidocene Climatic optimum has been dated around 14-16 Ma, see Zachos et al., 2008), initially diverging species should have had more tolerance to higher temperatures than they have now. In Valeriana that is more likely because many species related to the Páramo clade are found out of high-elevation habitats (Bell and Donoghue, 2005). Palazzesi et al. (2012) argue for a northward displacement of an originally south-temperate floristic element with climatic cooling, eastern Patagonian aridization and Andean uplift and this could explain various "too old" lineages nowadays restricted to Andean habitats in groups such as Ranunculaceae, Geraniales, Apiaceae. This argument is also in line with the relatively common phenomenon of south-to-north diversifications in the high Andes and along the Andean slopes, as shown for, e.g., Malesherbia (Gengler-Nowak, 2002). Overall, the detailed spatial patterns of Andean diversifications are still very incompletely understood, not least because most phylogenies use a rough "geographical subdivision" pattern for interpreting historical biogeography instead of analysing explicit distribution data.

The range of ages obtained for Andean lineages $(\sim 20-1 \mathrm{Ma})$ are similar to those reported for several lineages on the QinghaiTibetan Plateau (QTP; Wen et al., 2014). This may be due to the fact that the Andes and the QTP are of similar age (Favre et al., 2014). However, the relatively high frequency of Miocene or younger Angiosperm diversifications revealed by molecular phylogenies in relation to older ones suggests that a further possibility must also be taken into account: These diversifications may respond to the age constraints given by the origin of Angiosperms in time. This origin has been dated to the Early Jurassic the oldest (Magallón, 2010; Magallón et al., 2013). This time constraint imposes a boundary for diversification of modern lineages within the Angiosperms.
A range of published papers highlight the strong biogeographical connections between the Andean region and neighboring areas of Central America, eastern and western South America, as well as with more distant regions, such as North America, Oceania and Mascarenes. Biogeographical connections between the Andes and different areas of the Neotropics shown in molecular phylogenies confirm the long recognized mixed character of the Andean flora (Katinas et al., 1999). All connections with neighboring areas seem to have originated in Miocene times, or later. In particular, the closing of the Panama Isthmus might have been an important event for many lineages, which experienced floristic exchanges with Central America since Miocene times. The importance of the closing of the Panama Isthmus has long been claimed in Neotropical biogeography (e.g., Graham, 2011b). However, the closing of the Panama Isthmus must have occurred before the Pliocene in order to explain plant interchanges between Central and South America (Cody et al., 2010). Older ages for the closing of the Panama Isthmus have indeed been recently proposed by Farris et al. (2011), which has begun to be acknowledged by biogeographers (e.g., Antunes Carvalho and Renner, 2012; Hughes et al., 2013). However, few explicit analyses have included altitudinal species/lineage distributions in the discussion and a role of the closing of the Panama Isthmus in the exchange between montane and alpine biota is very implausible.

In summary, the data available in the literature confirm a temporal time-frame for most Neotropical diversifications which roughly agrees with Andean uplift, but also point to a complex history of the Andean flora (Antonelli and Sanmartín, 2011b; Rull, 2011a). As long as there are controversial models of uplift history, rigorous hypothesis testing must wait and each taxonomic group tends to have independent histories. There can be little doubt that diversification was driven by a range of processes, some directly linked to Andean uplift, such as climate changes and new ecological niches, others rather based in biotic responses such as polyploidization, morphological and physiological adaptations, and shifts in plant-pollinators interactions. Evaluation of the relative importance of these drivers is still a pending task in Neotropical biogeography.

\section{FUNDING}

German Academic Exchange Service (DAAD), SYNTHESYS, Nees Institute for Biodiversity of Plants, University of Bonn.

\section{ACKNOWLEDGMENT}

We are grateful to Hartmut Hilger (Berlin) for granting permission to publish his pictures, to Patricio Pliscoff (Santiago) for the map of Figure 1 and to the reviewers for comments.

\section{SUPPLEMENTARY MATERIAL}

The Supplementary Material for this article can be found online at: http://www.frontiersin.org/journal/10.3389/fevo.2014.00027/ abstract

Divergence times of Andean diversifications according to the major processes discussed in the text. Data on number of species, distribution, and habitat were obtained from the cited works, from Mabberley (2008), or from taxonomic treatments of the groups. Presence in the high-Andes were obtained from the cited 
works, and from Sklenář et al. (2005), Jørgensen and Ulloa Ulloa (1994), Freiberg (1985), Arroyo et al. (1992), Muñoz-Schick et al. (2000), and Brako and Zarucchi (1993). For references see main text.

\section{REFERENCES}

Aalto, R., Dunne, T., and Guyot, J. L. (2006). Geomorphic controls on Andean denudation rates. J. Geol. 114, 85-99. doi: 10.1086/498101

Alpers, C. N., and Brimhall, G. H. (1988). Middle miocene climatic change in the Atacama Desert, northern Chile: evidence from supergene mineralization at La Escondida. Geol. Soc. Am. Bull. 100, 1640-1656. doi: 10.1130/00167606(1988)100<1640:MMCCIT>2.3.CO;2

Anderson, E. F. (2005). Das Große Kakteen-Lexikon. Ulmer, Stuttgart.

Anderson, W. R. (2013). Origins of Mexican Malpighiaceae. Acta Bot. Mex. 104, $107-156$.

Antonelli, A., Nylander, J. A. A., Persson, C., and Sanmartín, I. (2009). Tracing the impact of the Andean uplift on Neotropical plant evolution. Proc. Natl. Acad. Sci. U.S.A. 106, 9749-9754. doi: 10.1073/pnas.0811421106

Antonelli, A., and Sanmartín, I. (2011a). Mass extinction, gradual cooling, or rapid radiation?: reconstructing the spatiotemporal evolution of the ancient Angiosperm genus Hedyosmum (Chloranthaceae) using empirical and simulated approaches. Syst. Biol. 60, 596-615. doi: 10.1093/sysbio/ syr062

Antonelli, A., and Sanmartín, I. (2011b). Why are there so many plant species in the Neotropics? Taxon 60, 403-414.

Antunes Carvalho, F., and Renner, S. S. (2012). A dated phylogeny of the papaya family (Caricaceae) reveals the crop's closest relatives and the family's biogeographic history. Mol. Phylogenet. Evol. 65, 46-53. doi: 10.1016/j.ympev.2012.05.019

Arakaki, M., Christin, P.-A., Nyffeler, R., Lendel, A., Eggli, U., Ogburn, R. M., et al. (2011). Contemporaneous and recent radiations of the World's major succulent plant lineages. Proc. Natl. Acad. Sci. U.S.A. 108, 8379-8384. doi: 10.1073/pnas. 1100628108

Arancibia, G., Matthews, S. J., and de Arce, C. P. (2006). K-Ar and Ar-40/Ar-39 geochronology of supergene processes in the Atacama Desert, northern Chile: tectonic and climatic relations. J. Geol. Soc. 163, 107-118. doi: 10.1144/0016764904-161

Arroyo, M. T. K., Bohlen, C. P. V., Cavieres, L., and Marticorena, C. (1992). Survey of the alpine flora of Torres del Paine National Park, Chile. Gayana Bot. 49, 47-70.

Arroyo, M. T. K., Castor, C., Marticorena, C., Cavieres, L., Muñoz, M., Matthei, O., et al. (1998). The flora of Llullaillaco National Park located in the transitional winter-summer rainfall area of the northern Chilean Andes. Gayana Bot. 55, 93-110.

Arroyo, M. T. K., Squeo, F., Veit, H., Cavieres, L., León, P., and Belmonte, E. (1997). "Flora and vegetation of northern Chilean Andes," in II Simposio Internacional de Estudios Altiplnicos (Santiago: Universidad de Chile), 167-178.

Baranzelli, M. C., Johnson, L. A., Cosacov, A., and Sérsic, A. N. (2014). Historical and ecological divergence among populations of Monttea chilensis (Plantaginaceae), an endemic endangered shrub bordering the Atacama Desert, Chile. Evol. Ecol. 28, 751-774. doi: 10.1007/s10682-0149694-y

Bardon, L., Chamagne, J., Dexter, K. G., Sothers, C. A., Prance, G. T., and Chave, J. (2013). Origin and evolution of Chrysobalanaceae: insights into the evolution of plants in the Neotropics. Bot. J. Linn. Soc. 171, 19-37. doi: 10.1111/j.10958339.2012.01289.x

Barreda, V., and Palazzesi, L. (2007). Patagonian vegetation turnovers during the Paleogene-Early Neogene: origin of arid-adapted floras. Bot. Rev. 73, 31-50. doi: 10.1663/0006-8101(2007)73[31:PVTDTP]2.0.CO;2

Barthlott, W., Mutke, J., Rafiqpoor, M. D., Kier, G., and Kreft, H. (2005). Global centres of vascular plant diversity. Nova Acta Leopold. 92, 61-83.

Bayona, G., Cortés, M., Jaramillo, C., Ojeda, G., Aristizabal, J. J., and Reyes-Harker, A. (2008). An integrated analysis of an orogen-sedimentary basin pair: latest Cretaceous-Cenozoic evolution of the linked Eastern Cordillera orogen and the Llanos foreland basin of Colombia. Geol. Soc. Am. Bull. 120, 1171-1197. doi: 10.1130/B26187.1

Becerra, J. X., Noge, K., Olivier, S., and Venable, D. L. (2012). The monophyly of Bursera and its impact for divergence times of Burseraceae. Taxon 61, 333-343.
Bell, C. D., and Donoghue, M. J. (2005). Phylogeny and biogeography of Valerianaceae (Dipsacales) with special reference to the South American valerians. Organ. Divers. Evol. 5, 147-159. doi: 10.1016/j.ode.2004.10.014

Bell, C. D., Kutschker, A., and Arroyo, M. T. (2012). Phylogeny and diversification of Valerianaceae (Dipsacales) in the Southern Andes. Mol. Phylogenet. Evol. 63, 724-737. doi: 10.1016/j.ympev.2012.02.015

Bermúdez, M. A., Kohn, B. P., van der Beek, P. A., Bernet, M., O’Sullivan, P. B., and Shagam, R. (2010). Spatial and temporal patterns of exhumation across the Venezuelan Andes: implications for cenozoic Caribbean geodynamics. Tectonics 29, TC5009. doi: 10.1029/2009TC002635

Berry, P. E. (1989). A systematic revision of Fuchsia sect. Quelusia (Onagraceae). Ann. Missouri Bot. Gard. 76, 532-584. doi: 10.2307/2399499

Berry, P. E., Hahn, W. J., Sytsma, K. J., Hall, J. C., and Mast, A. (2004). Phylogenetic relationships and biogeography of Fuchsia (Onagraceae) based on noncoding nuclear and chloroplast DNA data. Am. J. Bot. 91, 601-614. doi: 10.3732/ajb.91.4.601

Biffin, E., Conran, J. G., and Lowe, A. J. (2011). Podocarp evolution: a molecular phylogenetic perspective. Smithson. Contrib. Bot. 95, 1-20. doi: 10.5479/si. 0081024X.95.1

Blisniuk, P. M., Stern, L. A., Chamberlain, C. P., Idleman, B., and Zeitler, P. K. (2005). Climatic and ecologic changes during Miocene surface uplift in the southern Patagonian Andes. Earth Planet. Sci. Lett. 230, 125-142. doi: 10.1016/j.epsl.2004.11.015

Bradford, J. C. (2002). Molecular phylogenetics and morphological evolution in Cunonieae (Cunoniaceae). Ann. Missouri Bot. Gard. 89, 491-503. doi: $10.2307 / 3298592$

Brako, L., and Zarucchi, J. L. (1993). Catalogue of the flowering plants and gymnosperms of Peru. Monogr. Syst. Bot. Missouri Bot. Gard. 45, 1-1286.

Buytaert, W., Célleri, R., and Timbe, L. (2009). Predicting climate change impacts on water resources in the tropical Andes: effects of GCM uncertainty. Geophys. Res. Lett. 36, L07406. doi: 10.1029/2008GL037048

Catalano, S. A., Vilardi, J. C., Tosto, D., and Saidman, B. O. (2008). Molecular phylogeny and diversification history of Prosopis (Fabaceae: Mimosoideae). Biol. J. Linn. Soc. 93, 621-640. doi: 10.1111/j.1095-8312.2007.00907.x

Chacón, J., de Assis, M. C., Meerow, A. W., and Renner, S. S. (2012). From east Gondwana to Central America: historical biogeography of the Alstroemeriaceae. J. Biogeogr. 39, 1806-1818. doi: 10.1111/j.1365-2699.2012.02749.x

Chacón, J., Madriñán, S., Chase, M. W., and Bruhl, J. J. (2006). Molecular phylogenetics of Oreobolus (Cyperaceae) and the origin and diversification of the American species. Taxon 55, 359-366. doi: 10.2307/25065583

Cheng, J., and Xie, L. (2014). Molecular phylogeny and historical biogeography of Caltha (Ranunculaceae) based on analyses of multiple nuclear and plastid sequences. J. Syst. Evol. 52, 51-67. doi: 10.1111/jse.12051

Cody, S., Richardson, J. E., Rull, V., Ellis, C., and Pennington, R. T. (2010). The great american biotic interchange revisited. Ecography 33, 326-332. doi: 10.1111/j. 1600-0587.2010.06327.x

Comas, C. I., Confalonieri, V. A., and Hunziker, J. H. (1998). The genus Bulnesia revisited: a cladistic analysis of seed protein data. Biochem. Syst. Ecol. 26, 611-618. doi: 10.1016/S0305-1978(98)00030-1

Davies, A. (2010). Chaetanthera and Oriastrum: A Systematic Revision of Chaetanthera Ruiz and Pav. and The Reinstatement of Oriastrum Poepp. \& Endl. (Asteraceae: Mutisieae). Saarbrücken: Südwestdeutscher Verlag für Hochschulschriften.

Davis, C. C., and Anderson, W. R. (2010). A complete generic phylogeny of Malpighiaceae inferred from nucleotide sequence data and morphology. Am. J. Bot. 97, 2031-2048. doi: 10.3732/ajb.1000146

Dillon, M. O., Sagástegui-Alva, A., Sánchez Vega, I., Llatas Quiroz, S., and Hensold, N. (1995). "Floristic inventory and biogeograhic analysis of montane forests in northwestern Peru," in Biodiversity and Conservation of Neotropical Montane Forests, eds S. P. Churchill, H. Balslev, E. Forero, and J. L. Luteyn (New York, NY: New York Botanical Garden), 251-269.

Dillon, M. O., Tu, T. Y., Xie, L., Quipuscoa-Silvestre, V., and Wen, J. (2009). Biogeographic diversification in Nolana (Solanaceae), a ubiquitous member of the Atacama and Peruvian deserts along the western coast of South America. J. Syst. Evol. 47, 457-476. doi: 10.1111/j.1759-6831.2009.00040.x

Doan, T. M. (2003). A south-to-north biogeographic hypothesis for Andean speciation: evidence from the lizard genus Proctoporus (Reptilia Gymnophthalmidae). J. Biogeogr. 30, 361-374. doi: 10.1046/j.1365-2699.2003. 00833.x 
Drew, B. T., and Sytsma, K. J. (2013). The South American radiation of Lepechinia (Lamiaceae): phylogenetics, divergence times and evolution of dioecy. Bot. J. Linn. Soc. 171, 171-190. doi: 10.1111/j.1095-8339.2012.01325.x

Drummond, C. S. (2008). Diversification of Lupinus (Leguminosae) in the western New World: derived evolution of perennial life history and colonization of montane habitats. Mol. Phylogenet. Evol. 48, 408-421. doi: 10.1016/j.ympev.2008.03.009

Drummond, C. S., Eastwood, R. J., Miotto, S. T. S., and Hughes, C. E. (2012). Multiple continental radiations and correlates of diversification in Lupinus (Leguminosae): testing for key innovation with incomplete taxon sampling. Syst. Biol. 61, 443-460. doi: 10.1093/sysbio/syr126

Ehlers, T. A., and Poulsen, C. J. (2009). Influence of Andean uplift on climate and paleoaltimetry estimates. Earth Planet. Sci. Lett. 281, 238-248. doi: 10.1016/j.epsl.2009.02.026

Emadzade, K., and Hörandl, E. (2011). Northern Hemisphere origin, transoceanic dispersal, and diversification of Ranunculeae DC. (Ranunculaceae) in the Cenozoic. J. Biogeogr. 38, 517-530. doi: 10.1111/j.1365-2699.2010.02404.x

Emshwiller, E. (2002). Biogeography of the Oxalis tuberosa Alliance. Bot. Rev. 68, 128-152. doi: 10.1663/0006-8101(2002)068[0128:BOTOTA]2.0.CO;2

Emshwiller, E., and Doyle, J. (1998). Origins of domestication and polyploidy in oca (Oxalis tuberosa: Oxalidaceae): nrDNA ITS data. Am. J. Bot. 85, 975-975. doi: $10.2307 / 2446364$

Emshwiller, E., and Doyle, J. J. (2002). Origins of domestication and polyploidy in oca (Oxalis tuberosa: Oxalidaceae). 2. Chloroplast-expressed glutamine synthetase data. Am. J. Bot. 89, 1042-1056. doi: 10.3732/ajb.89.7.1042

Encinas, A., Zambrano, P. A., Finger, K. L., Valencia, V., Buatois, and Duhart, P. (2013). Implications of deep-marine Miocene deposits on the evolution of the North Patagonian Andes. J. Geol. 121, 215-238. doi: 10.1086/669976

Erikson, J. P., Kelley, S. A., Osmolovsky, P., and Verosub, K. L. (2012). Linked basin sedimentation and orogenic uplift: the Neogene Barinas basin sediments derived from the Venezuelan Andes. J. South Am. Earth Sci. 39, 138-156. doi: 10.1016/j.jsames.2012.04.002

Ezcurra, C. (2002). Phylogeny, morphology, and biogeography of Chuquiraga, an Andean-Patagonian genus of Asteraceae-Barnadesioideae. Bot. Rev. 68, 153-170. doi: 10.1663/0006-8101(2002)068[0153:PMABOC]2.0.CO;2

Farag, M. A., Weigend, M., Luebert, F., Brokamp, G., and Wessjohann, L. A. (2013). Phytochemical, phylogenetic, and anti-inflammatory evaluation of 43 Urtica accessions (stinging nettle) based on UPLCQ-TOF-MS metabolomic profiles. Phytochemistry 96, 170-183. doi: 10.1016/j.phytochem.2013.09.016

Farris, D. W., Jaramillo, C., Bayona, G., Restrepo-Moreno, S. A., Montes, C., Cardona, A., et al. (2011). Fracturing of the Panamanian isthmus during initial collision with South America. Geology 39, 1007-1010. doi: 10.1130/G32237.1

Favre, A., Päckert, M., Pauls, S. U., Jähnig, S. C., Uhl, D., Michalak, I., et al. (2014). The role of the uplift of the Qinghai-Tibetan plateau for the evolution of Tibetan biotas. Biol. Rev. doi: 10.1111/brv.12107. [Epub ahead of print].

Feodorova, T. A., Voznesenskaya, E. V., Edwards, G. E., and Roalson, E. H. (2010). Biogeographic patterns of diversification and the origins of $\mathrm{C} 4$ in Cleome (Cleomaceae). Syst. Bot. 35, 811-826. doi: 10.1600/036364410X539880

Filipowicz, N., and Renner, S. S. (2012). Brunfelsia (Solanaceae): a genus evenly divided between South America and radiations on Cuba and other Antillean islands. Mol. Phylogenet. Evol. 64, 1-11. doi: 10.1016/j.ympev.2012.02.026

Fine, P. V. A., Daly, D. C., Villa Muñoz, G., Mesones, I., and Cameron, K. M. (2005). The contribution of edaphic heterogeneity to the evolution and diversity of Burseraceae trees in the western Amazon. Evolution 59, 1464-1478. doi: 10.1554/04-745

Fosdick, J. C., Grove, M., Hourigan, J. K., and Calderón, M. (2013). Retroarc deformation and exhumation near the end of the Andes, southern Patagonia. Earth Planet. Sci. Lett. 361, 504-517. doi: 10.1016/j.epsl.2012.12.007

Freiberg, H. M. (1985). Vegetationskundliche Untersuchungen an südchilenischen Vulkanen. Bonn. Geogr. Abh. 70, 1-170.

Gardner, A. G., Vaio, M., Guerra, M., and Emshwiller, E. (2012). Diversification of the American bulb-bearing Oxalis (Oxalidaceae): dispersal to North America and modification of the tristylous breeding system. Am. J. Bot. 99, 152-164. doi: 10.3732/ajb.1100152

Garreaud, R. D. (2009). The Andes climate and weather. Adv. Geosci. 22, 3-11. doi: 10.5194/adgeo-22-3-2009

Garreaud, R. D., Vuille, M., Compagnucci, R., and Marengo, J. (2009). Present-day South American climate. Palaeogeogr. Palaeoclimatol. Palaeoecol. 281, 180-195. doi: $10.1016 /$ j.palaeo.2007.10.032
Garzione, C. N., Hoke, G. D., Libarkin, J. C., Withers, S., MacFadden, B., Eiler, J., et al. (2008). Rise of the Andes. Science 320, 1304-1307. doi: 10.1126/science. 1148615

Gengler-Nowak, K. M. (2002). Reconstruction of the biogeographical history of Malesherbiaceae. Bot. Rev. 68, 171-188. doi: 10.1663/0006-8101(2002)068 [0171:ROTBHO]2.0.CO;2

Gentry, A. H. (1982). Neotropical floristic diversity: phytogeographical connections between Central and South America, Pleistocene climatic fluctuations, or an accident of the Andean orogeny? Ann. Missouri Bot. Gard. 69, 557-593. doi: $10.2307 / 2399084$

Ghosh, P., Garzione, C. N., and Eiler, J. M. (2006). Rapid uplift of the Altiplano revealed through ${ }^{1} 3 \mathrm{C}-{ }^{1} 8 \mathrm{O}$ bonds in paleosol carbonates. Science $311,511-515$. doi: $10.1126 /$ science. 1119365

Givnish, T. J., Barfuss, M. H. J., Ee, B. V., Riina, R., Schulte, K., Horres, R., et al. (2014). Adaptive radiation, correlated and contingent evolution, and net species diversification in Bromeliaceae. Mol. Phylogenet. Evol. 71, 55-78. doi: 10.1016/j.ympev.2013.10.010

Givnish, T. J., Barfuss, M. H. J., van Ee, B., Riina, R., Schulte, K., Horres, R., et al. (2011). Phylogeny, adaptive radiation, and historical biogeography in Bromeliaceae: insights from an eight-locus plastid phylogeny. Am. J. Bot. 98, 872-895. doi: 10.3732/ajb.1000059

Graham, A. (2011a). A Natural History of The New World: The Ecology and Evolution of Plants in the Americas. Chicago: University of Chicago Press.

Graham, A. (2011b). The age and diversification of terrestrial New World ecosystems through Cretaceous and Cenozoic time. Am. J. Bot. 98, 336-351. doi: 10.3732/ajb. 1000353

Graham, A., Gregory-Wodzicki, K. M., and Wright, K. L. (2001). Studies in Neotropical paleobotany. XV. A Mio-Pliocene palynoflora from the Eastern Cordillera, Bolivia: implications for the uplift history of the Central Andes. Am. J. Bot. 88, 1545-1557. doi: 10.2307/3558398

Gregory-Wodzicki, K. M. (2000). Uplift history of the Central and northern Andes: a review. Geol. Soc. Am. Bull. 112, 1091-1105. doi: 10.1130/00167606(2000)112<1091:UHOTCA >2.0.CO;2

Gruenstaeudl, M., Urtubey, E., Jansen, R. K., Samuel, R., Barfuss, M. H. J., and Stuessy, T. F. (2009). Phylogeny of Barnadesioideae (Asteraceae) inferred from DNA sequence data and morphology. Mol. Phylogenet. Evol. 51, 572-587. doi: 10.1016/j.ympev.2009.01.023

Hartley, A. J. (2003). Andean uplift and climate change. J. Geol. Soc. 160, 7-10. doi: 10.1144/0016-764902-083

Hartley, A. J., and Rice, C. (2005). Controls on supergene enrichment of porphyry copper deposits in the Central Andes: a review and discussion. Miner. Deposita 40, 515-525. doi: 10.1007/s00126-005-0017-7

Hartley, A. J., Sempere, T., and Wörner, G. (2007). A comment on "Rapid late Miocene rise of the Bolivian Altiplano: evidence for removal of mantle lithosphere" by C. N. Garzione et al. [Earth Planet. Sci. Lett. 241 (2006) 543-556]. Earth Planet. Sci. Lett. 259, 625-629. doi: 10.1016/j.epsl.2007.04.012

Harvey, P. H., May, R. M., and Nee, S. (1994). Phylogenies without fossils. Evolution 48, 523-529. doi: 10.2307/2410466

Heenan, P. B., and Smissen, R. D. (2013). Revised circumscription of Nothofagus and recognition of the segregate genera Fuscospora, Lophozonia, and Trisyngyne (Nothofagaceae). Phytotaxa 146, 1-31. doi: 10.11646/phytotaxa.146.1.1

Heibl, C., and Renner, S. S. (2012). Distribution models and a dated phylogeny for Chilean Oxalis species reveal occupation of new habitats by different lineages, not rapid adaptive radiation. Syst. Biol. 61, 823-834. doi: 10.1093/sysbio/ sys034

Henning, T., Quandt, D., Grosse-Veldmann, B., Monro, A., and Weigend, M. (2014). Weeding the Nettles II: a delimitation of "Urtica dioica L." (Urticaceae) based on morphological and molecular data, including a rehabilitation of Urtica gracilis Ait. Phytotaxa 162, 61-83. doi: 10.11646/phytotaxa.162.2.1

Hernández-Hernández, T., Brown, J. W., Schlumpberger, B. O., Eguiarte, L. E., and Magallón, S. (2014). Beyond aridification: multiple explanations for the elevated diversification of cacti in the New World Succulent Biome. New Phytol. 202, 1382-1397. doi: 10.1111/nph.12752

Hershkovitz, M. A., Arroyo, M. T. K., Bell, C., and Hinojosa, L. F. (2006). Phylogeny of Chaetanthera (Asteraceae: Mutisieae) reveals both ancient and recent origins of the high elevation lineages. Mol. Phylogenet. Evol. 41, 594-605. doi: 10.1016/j.ympev.2006.05.003

Hijmans, R. J., Gavrilenko, T., Stephenson, S., Bamberg, J., Salas, A., and Spooner, D. M. (2007). Geographical and environmental range expansion through 
polyploidy in wild potatoes (Solanum section Petota). Global Ecol. Biogeogr. 16, 485-495. doi: 10.1111/j.1466-8238.2007.00308.x

Hoffmann, M. H., Schneider, J., Hase, P., and Röser, M. (2013). Rapid and recent world-wide diversification of bluegrasses (Poa, Poaceae) and related genera. PLoS ONE 8:e60061. doi: 10.1371/journal.pone.0060061

Hoke, G. D., Isacks, B. L., Jordan, T. E., Blanco, N., Tomlinson, A. J., and Ramezani, J. (2007). Geomorphic evidence for post-10 ma uplift of the western flank of the Central Andes $18^{\circ} 30^{\prime}-22^{\circ}$ S. Tectonics 26, TC5021. doi: 10.1029/2006TC 002082

Hoorn, C. (1993). Marine incursions and the influence of Andean tectonics on the Miocene depositional history of northwestern Amazonia: results of a palynostratigraphic study. Palaeogeogr. Palaeoclimatol. Palaeoecol. 105, 267-309. doi: 10.1016/0031-0182(93)90087-Y

Hoorn, C., Guerrero, J., Sarmiento, G. A., and Lorente, M. A. (1995). Andean tectonics as a cause for changing drainage patterns in Miocene northern South America. Geology 23, 237-240. doi: 10.1130/0091-7613(1995)023<0237:ATAACF > 2.3.CO;2

Hoorn, C., Mosbrugger, V., Mulch, A., and Antonelli, A. (2013). Biodiversity from mountain building. Nat. Geosci. 6, 154. doi: 10.1038/ngeo 1742

Hoorn, C., Wesselingh, F. P., Steege, H. T., Bermudez, M. A., Mora, A., Sevink, J., et al. (2011). Origins of biodiversity - response. Science 331, 399-400. doi: 10.1126/science.331.6016.399

Hoorn, C., Wesselingh, F. P., ter Steege, H., Bermudez, M. A., Mora, A., Sevink, J., et al. (2010). Amazonia through time: Andean uplift, climate change, landscape evolution, and biodiversity. Science 330, 927-931. doi: 10.1126/science. 1194585

Houston, J. (2006). Variability of precipitation in the Atacama Desert: its causes and hydrological impact. Int. J. Climatol. 26, 2181-2198. doi: 10.1002/joc.1359

Houston, J., and Hartley, A. J. (2003). The central Andean west-slope rainshadow and its potential contribution to the origin of hyper-aridity in the Atacama Desert. Int. J. Climatol. 23, 1453-1464. doi: 10.1002/joc.938

Hughes, C., and Eastwood, R. (2006). Island radiation on a continental scale: Exceptional rates of plant diversification after uplift of the Andes. Proc. Natl. Acad. Sci. U.S.A. 103, 10334-10339. doi: 10.1073/pnas.0601928103

Hughes, C. E., Pennington, R. T., and Antonelli, A. (2013). Neotropical plant evolution: assembling the big picture. Bot. J. Linn. Soc. 171, 1-18. doi: 10.1111/boj.12006

Inda, L. A., Segarra-Moragues, J. G., Müller, J., Peterson, P. M., and Catalán, P. (2008). Dated historical biogeography of the temperate Loliinae (Poaceae, Pooideae) grasses in the northern and southern hemispheres. Mol. Phylogenet. Evol. 46, 932-957. doi: 10.1016/j.ympev.2007.11.022

Jabaily, R. S., and Sytsma, K. J. (2013). Historical biogeography and life-history evolution of Andean Puya (Bromeliaceae). Bot. J. Linn. Soc. 171, 201-224. doi: 10.1111/j.1095-8339.2012.01307.x

Jordan, T. E., Burns, W. M., Veiga, R., Pángaro, F., Copeland, P., Kelley, S., et al. (2001). Extension and basin formation in the Southern Andes caused by increased convergence rate: a mid-Cenozoic trigger for the Andes. Tectonics 20, 308-324. doi: 10.1029/1999TC001181

Jørgensen, P. M., and Ulloa Ulloa, C. (1994). Seed plants of the high Andes of Ecuador: a checklist. AAU Rep. 34, 1-462.

Katinas, L., and Crisci, J. V. (2000). Cladistic and biogeographic analyses of the genera Moscharia and Polyachyrus (Asteraceae, Mutisieae). Syst. Bot. 25, 33-46. doi: $10.2307 / 2666671$

Katinas, L., Crisci, J. V., Jabaily, R. S., Williams, C., Walker, J., Drew, B., et al. (2008). Evolution of secondary heads in Nassauviinae (Asteraceae, Mutisieae). Am. J. Bot. 95, 229-240. doi: 10.3732/ajb.95.2.229

Katinas, L., Morrone, J. J., and Crisci, J. V. (1999). Track analysis reveals the composite nature of the Andean biota. Aust. J. Bot. 47, 111-130. doi: 10.1071/BT97049

Kay, K. M., Reeves, P. A., Olmstead, R. G., and Schemske, D. W. (2005). Rapid speciation and the evolution of hummingbird pollination in neotropical Costus subgenus Costus (Costaceae): evidence from nrDNA ITS and ETS sequences. Am. J. Bot. 92, 1899-1910. doi: 10.3732/ajb.92.11.1899

Knopf, P., Schulz, C., Little, D. P., Stützel, T., and Stevenson, D. W. (2012). Relationships within Podocarpaceae based on DNA sequence, anatomical, morphological, and biogeographical data. Cladistics 28, 271-299. doi: 10.1111/j.1096-0031.2011.00381.x

Körner, C. (1998). A re-assessment of high elevation treeline positions and their explanation. Oecologia 115, 445-459. doi: 10.1007/s004420050540
Körner, C., Paulsen, J., and Spehn, E. M. (2011). A definition of mountains and their bioclimatic belts for global comparisons of biodiversity data. Alp. Bot. 121, 73-78. doi: 10.1007/s00035-011-0094-4

Kubitzki, K. (1989). The ecogeographical differentiation of Amazonian inundation forests. Plant Syst. Evol. 162, 285-304. doi: 10.1007/BF00936922

Kuntze, O. (1895). Geogenetische Beiträge. Lepzig: Gressner \& Schramm.

Lamb, S., and Davis, P. (2003). Cenozoic climate change as a possible cause for the rise of the Andes. Nature 425, 792-797. doi: 10.1038/nature02049

Landrum, L. R. (1981). A monograph of the genus Myrceugenia (Myrtaceae). Flora Neotrop. 29, 1-135.

Lease, R. O., and Ehlers, T. A. (2013). Incision into the eastern Andean plateau during Pliocene cooling. Science 341, 774-776. doi: 10.1126/science. 1239132

Leier, A., McQuarrie, N., Garzione, C., and Eiler, J. (2013). Stable isotope evidence for multiple pulses of rapid surface uplift in the Central Andes, Bolivia. Earth Planet. Sci. Lett. 371-372, 49-58. doi: 10.1016/j.epsl.2013.04.025

Linares-Palomino, R., Pennington, R. T., and Bridgewater, S. (2003). The phytogeography of the seasonally dry tropical forests in Equatorial Pacific South America. Candollea 58, 473-499.

Lohmann, L. G., Bell, C. D., Calió, M. F., and Winkworth, R. C. (2013). Pattern and timing of biogeographical history in the Neotropical tribe Bignonieae (Bignoniaceae). Bot. J. Linn. Soc. 171, 154-170. doi: 10.1111/j.10958339.2012.01311.x

Luebert, F. (2011). Hacia un fitogeografía histórica del Desierto de Atacama. Rev. Geogr. Norte Grand. 50, 105-133. doi: 10.4067/S0718-34022011000300007

Luebert, F., Brokamp, G., Wen, J., Weigend, M., and Hilger, H. H. (2011a). Phylogenetic relationships and morphological diversity in Neotropical Heliotropium (Heliotropiaceae). Taxon 60, 663-680.

Luebert, F., Hilger, H. H., and Weigend, M. (2011b). Diversification in the Andes: age and origins of South American Heliotropium lineages (Heliotropiaceae, Boraginales). Mol. Phylogenet. Evol. 61, 90-102. doi: 10.1016/j.ympev.2011.06.001

Luebert, F., and Pliscoff, P. (2006). Sinopsis Bioclimática y Vegetacional de Chile. Santiago: Editorial Universitaria.

Luebert, F., and Wen, J. (2008). Phylogenetic analysis and evolutionary diversification of Heliotropium sect. Cochranea (Heliotropiaceae) in the Atacama Desert. Syst. Bot. 33, 390-402. doi: 10.1600/036364408784571635

Luebert, F., Wen, J., and Dillon, M. O. (2009). Systematic placement and biogeographical relationships of the monotypic genera Gypothamnium and Oxyphyllum (Asteraceae: Mutisioideae) from the Atacama Desert. Bot. J. Linn. Soc. 159, 32-51. doi: 10.1111/j.1095-8339.2008.00926.x

Mabberley, D. J. (2008). Mabberley's Plant Book. A Portable Dictionary of Plants, Their Classification and Uses, 3rd Edn. Cambridge: Cambridge University Press.

Madriñán, S., Cortés, A. J., and Richardson, J. E. (2013). Páramo is the world's fastest evolving and coolest biodiversity hotspot. Front. Genetics 4:192. doi: $10.3389 /$ fgene. 2013.00192

Magallón, S. (2010). Using fossils to break long branches in molecular dating: a comparison of relaxed clocks applied to the origin of Angiosperms. Syst. Biol. 59, 384-399. doi: 10.1093/sysbio/syq027

Magallón, S., Hilu, K. W., and Quandt, D. (2013). Land plant evolutionary timeline: gene effects are secondary to fossil constraints in relaxed clock estimation of age and substitution rates. Am. J. Bot. 100, 556-573. doi: 10.3732/ajb.1200416

Marquínez, X., Lohmann, L. G., Salatino, M. L. F., Salatino, A., and González, F. (2009). Generic relationships and dating of lineages in Winteraceae based on nuclear (ITS) and plastid (rpS16 and psbA-trnH) sequence data. Mol. Phylogenet. Evol. 53, 435-449. doi: 10.1016/j.ympev.2009.07.001

Martínez-Carretero, E. (1995). La Puna argentina: delimitación general y división en distritos florísticos. Bol. Soc. Argent. Bot. 31, 27-40.

Meudt, H. M., and Simpson, B. B. (2006). The biogeography of the austral, subalpine genus Ourisia (Plantaginaceae) based on molecular phylogenetic evidence: South American origin and dispersal to New Zealand and Tasmania. Biol. J. Linn. Soc. 87, 479-513. doi: 10.1111/j.1095-8312.2006.00584.x

Michelangeli, F. A., Guimaraes, P. J. F., Penneys, D. S., Almeda, F., and Kriebel, R. (2013). Phylogenetic relationships and distribution of New World Melastomeae (Melastomataceae). Bot. J. Linn. Soc. 171, 38-60. doi: 10.1111/j.1095-8339.2012.01295.x

Mora, A., Baby, P., Roddaz, M., Parra, M., Brusset, S., Hermoza, W., et al. (2010). "Tectonic history of the Andes and sub-Andean zones: implications for the development of the Amazon drainage basin," in Amazonia, Landscape and Species Evolution, eds C. Hoorn and F. P. Wesselingh (Oxford: Blackwell), 38-60. 
Moreira-Muñoz, A. (2011). Plant Geography of Chile. Dordrecht: Springer. doi: 10.1007/978-90-481-8748-5

Moreno, P. I., Villagrán, C., Marquet, P. A., and Marshall, L. G. (1994). Quaternary paleobiogeography of northern and central Chile. Rev. Chil. Hist. Nat. 67, 487-502.

Morrone, J. J. (2001). Biogeografía de América Latina y el Caribe, Vol. 3. Zaragoza: Manuales \& Tesis SEA.

Muñoz-Schick, M., Moreira-Muñoz, A., Villagrán, C., and Luebert, F. (2000). Caracterización florística y pisos de vegetación en los Andes de Santiago, Chile Central. Bol. Mus. Nac. Hist. Nat. Chile 49, 9-50.

Murillo-A., J., Ruiz-P., E., Landrum, L. R., Stuessy, T. F., and Barfuss, M. H. J. (2012). Phylogenetic relationships in Myrceugenia (Myrtaceae) based on plastid and nuclear DNA sequences. Mol. Phylogenet. Evol. 62, 764-776. doi: 10.1016/j.ympev.2011.11.021

Nagy, L., and Grabherr, G. (2009). The Biology of Alpine Habitats. Oxford: Oxford University Press.

Nicolas, A. N., and Plunkett, G. M. (2012). Untangling generic limits in Azorella, Laretia, and Mulinum (Apiaceae: Azorelloideae): insights from phylogenetics and biogeography. Taxon 61, 826-840.

Nicolas, A. N., and Plunkett, G. M. (2014). Diversification times and biogeographic patterns in Apiales. Bot. Rev. 80, 30-58. doi: 10.1007/s12229-014-9132-4

Nores, M. J., Simpson, B. B., Hick, P., Anton, A. M., and Fortunato, R. H. (2012). The phylogenetic relationships of four monospecific caesalpinioids (Leguminosae) endemic to southern South America. Taxon 61, 790-802.

Nürk, N. M., Scheriau, C., and Madriñán, S. (2013). Explosive radiation in high Andean Hypericum - rates of diversification among New World lineages. Front. Genet. 4:175. doi: 10.3389/fgene.2013.00175

Palazzesi, L., Gottschling, M., Barreda, V., and Weigend, M. (2012). First Miocene fossils of Vivianiaceae shed new light on phylogeny, divergence times, and historical biogeography of Geraniales. Biol. J. Linn. Soc. 107, 67-85. doi: 10.1111/j.1095-8312.2012.01910.x

Pankhurst, R. J., and Herve, F. (2007). "Introduction and overview," in The Geology of Chile, eds T. Moreno and W. Gibbons (London: Geological Society of London), 1-4.

Pennington, R. T., and Dick, C. W. (2010). "Diversification of the Amazonian flora and its relation to key geological and environmental events: a molecular perspective," in Amazonia, Landscape and Species Evolution, eds C. Hoorn and F. P. Wesselingh (Oxford: Blackwell), 373-385.

Pennington, R. T., Lavin, M., Prado, D. E., Pendry, C. A., Pell, S. K., and Butterworth, C. A. (2004). Historical climate change and speciation: Neotropical seasonally dry forest plants show patterns of both Tertiary and Quaternary diversification. Philos. Trans. R. Soc. B Biol. Sci. 359, 515-538. doi: 10.1098/rstb.2003.1435

Pennington, R. T., Lavin, M., Särkinen, T., Lewis, G. P., Klitgaard, B. B., and Hughes, C. E. (2010). Contrasting plant diversification histories within the Andean biodiversity hotspot. Proc. Natl. Acad. Sci. U.S.A. 107, 13783-13787. doi: 10.1073/pnas.1001317107

Pérez, F., Arroyo, M. T. K., Medel, R., and Hershkovitz, M. A. (2006). Ancestral reconstruction of flower morphology and pollination systems in Schizanthus (Solanaceae). Am. J. Bot. 93, 1029-1038. doi: 10.3732/ajb.93.7.1029

Perret, M., Chautems, A., Onofre de Araujo, A., and Salamin, N. (2013). Temporal and spatial origin of Gesneriaceae in the New World inferred from plastid DNA sequences. Bot. J. Linn. Soc. 171, 61-79. doi: 10.1111/j.1095-8339.2012.01303.x

Perret, M., Chautems, A., and Spichiger, R. (2006). Dispersal-vicariance analyses in the tribe Sinningieae (Gesneriaceae): a clue to understanding biogeographical history of the Brazilian Atlantic forest. Ann. Missouri Bot. Gard. 93, 340-358. doi: 10.3417/0026-6493(2006)93[340:DAITTS]2. $0 . \mathrm{CO} ; 2$

Pinto, R., and Luebert, F. (2009). Datos sobre la flora vascular del desierto costero de Arica y Tarapacá, Chile, y sus relaciones fitogeográficas con el sur de Perú. Gayana Bot. 66, 28-49. doi: 10.4067/S0717-66432009000100004

Pirie, M. D., Chatrou, L. W., Mols, J. B., Erkens, R. H. J., and Oosterhof, J. (2006). Andean-centred genera in the short-branch clade of Annonaceae: testing biogeographical hypotheses using phylogeny reconstruction and molecular dating. J. Biogeogr. 33, 31-46. doi: 10.1111/j.1365-2699.2005.01388.x

Ramos, M. E., Folguera, A., Fennell, L., Giménez, M., Litvak, V. D., Dzierma, Y., et al. (2014). Tectonic evolution of the North Patagonian Andes from field and gravity data $\left(39-40^{\circ} \mathrm{S}\right)$. J. South Am. Earth Sci. 51, 59-75. doi: 10.1016/j.jsames.2013.12.010
Refulio-Rodriguez, N. F., Columbus, J. T., Gillespie, L. J., Peterson, P. M., and Soreng, R. J. (2012). Molecular phylogeny of Dissanthelium (Poaceae: Pooideae) and its taxonomic implications. Syst. Bot. 37, 122-133. doi: 10.1600/036364412X616701

Regard, V., Saillard, M., Martinod, J., Audin, L., Carretier, S., Pedoja, K., et al. (2010). Renewed uplift of the Central Andes Forearc revealed by coastal evolution during the Quaternary. Earth Planet. Sci. Lett. 297, 199-210. doi: 10.1016/j.epsl.2010.06.020

Reich, M., Palacios, C., Vargas, G., Luo, S., Cameron, E., Leybourne, M., et al. (2009). Supergene enrichment of copper deposits since the onset of modern hyperaridity in the Atacama Desert, Chile. Miner. Deposita 44, 497-504. doi: 10.1007/s00126-009-0229-3

Richardson, J. E., Pennington, R. T., Pennington, T. D., and Hollingsworth, P. M. (2001). Rapid diversification of a species-rich genus of Neotropical rain forest trees. Science 293, 2242-2245. doi: 10.1126/science.1061421

Rodríguez, M. P., Carretier, S., Charrier, R., Saillard, M., Regard, V., Hérail, G., et al. (2013). Geochronology of pediments and marine terraces in northcentral Chile and their implications for Quaternary uplift in the western Andes. Geomorphology 180-181, 33-46. doi: 10.1016/j.geomorph.2012.09.003

Rull, V. (2011a). Neotropical biodiversity: timing and potential drivers. Trends Ecol. Evol. 26, 508-513. doi: 10.1016/j.tree.2011.05.011

Rull, V. (2011b). Origins of biodiversity. Science 331, 398-399. doi: 10.1126/science.331.6016.398-c

Rutllant, J. A., Fuenzalida, H., and Aceituno, P. (2003). Climate dynamics along the arid northern coast of Chile: the 1997-1998 Dinámica del Clima de la Región de Antofagasta (DICLIMA) experiment. J. Geophys. Res. 108, 4538. doi: 10.1029/2002JD003357

Särkinen, T., Bohs, L., Olmstead, R. G., and Knapp, S. (2013). A phylogenetic framework for evolutionary study of the nightshades (Solanaceae): a dated 1000-tip tree. BMC Evol. Biol. 13:214. doi: 10.1186/1471-2148-13-214

Särkinen, T., Pennington, R. T., Lavin, M., Simon, M. F., and Hughes, C. E. (2011). Evolutionary islands in the Andes: persistence and isolation explain high endemism in Andean dry tropical forests. J. Biogeogr. 39, 884-900. doi: 10.1111/j.1365-2699.2011.02644.x

Särkinen, T. E., Newman, M. F., Maas, P. J. M., Maas, H., Poulsen, A. D., Harris, D. J., et al. (2007). Recent oceanic long-distance dispersal and divergence in the amphi-atlantic rain forest genus Renealmia L.f. (Zingiberaceae). Mol. Phylogenet. Evol. 44, 968-980. doi: 10.1016/j.ympev.2007.06.007

Sauquet, H., Ho, S. Y. W., Gandolfo, M. A., Jordan, G. J., Wilf, P., Cantrill, D. J., et al. (2012). Testing the impact of calibration on molecular divergence times using a fossil-rich group: the case of Nothofagus (Fagales). Syst. Biol. 61, 289-313. doi: $10.1093 /$ sysbio/syr116

Saylor, J. E., and Horton, B. K. (2014). Nonuniform surface uplift of the Andean plateau revealed by deuterium isotopes in Miocene volcanic glass from southern Peru. Earth Planet. Sci. Lett. 387, 120-131. doi: 10.1016/j.epsl.2013.11.015

Schildgen, T. F., Ehlers, T. A., Whipp, D. M. J., van Soest, M. C., Whipple, K. X., and Hodges, K. V. (2009). Quantifying canyon incision and Andean plateau surface uplift, southwest Peru: a thermochronometer and numerical modeling approach. J. Geophys. Res. 114:F04014. doi: 10.1029/2009JF001305

Schlumpberger, B. O., and Renner, S. S. (2012). Molecular phylogenetics of Echinopsis (Cactaceae): polyphyly at all levels and convergent evolution of pollination modes and growth forms. Am. J. Bot. 99, 1335-1349. doi: 10.3732/ajb.1100288

Schmidt-Lebuhn, A. N., Fuchs, J., Hertel, D., Hirsch, H., Toivonen, J., and Kessler, M. (2010). An Andean radiation: polyploidy in the tree genus Polylepis (Rosaceae, Sanguisorbeae). Plant Biol. 12, 917-926. doi: 10.1111/j.14388677.2009.00297.x

Schmithüsen, J. (1956). Die raumliche Ordnung der chilenischen Vegetation. Bonn. Geogr. Abh. 17, 1-86.

Schütze, P., Freitag, H., and Weising, K. (2003). An integrated molecular and morphological study of the subfamily Suaedoideae Ulbr. (Chenopodiaceae). Plant Syst. Evol. 239, 257-286. doi: 10.1007/s00606-003-0013-2

Schwarzer, C., Huamaní, F. C., Cano, A., de la Torre, M. I., and Weigend, M. (2010). 400 years for long-distance dispersal and divergence in the Atacama Desert - insights from the Huaynaputina pumice slopes of Moquegua, Peru. J. Arid Environ. 74, 1540-1551. doi: 10.1016/j.jaridenv.2010.05.034

Sempere, T., Hartley, A., and Roperch, P. (2006). Comment on Rapid uplift of the Altiplano revealed through ${ }^{13} \mathrm{C}-{ }^{18} \mathrm{O}$ bonds in paleosol carbonates. Science 314, 760. doi: 10.1126/science.1132837 
Sepulchre, P., Sloan, L. C., Snyder, M., and Fiechter, J. (2009). Impacts of Andean uplift on the Humboldt current system: a climate model sensitivity study. Paleoceanography 24:PA4215. doi: 10.1029/2008PA001668

Simon, R., Fuentes, A. F., and Spooner, D. M. (2011). Biogeographic implications of the striking discovery of a 4,000 kilometer disjunct population of the wild potato Solanum morelliforme in South America. Syst. Bot. 36, 1062-1067. doi: 10.1600/036364411X605065

Simpson, B. B. (1975). Pleistocene changes in the flora of the high tropical Andes. Paleobiology 1, 273-294.

Simpson, B. B. (1983). An historical phytogeography of the high Andean flora. Rev. Chil. Hist. Nat. 56, 109-122.

Simpson, B. B., Arroyo, M. T. K., Sipe, S., de Moraes, M. D., and McDill, J. (2009). Phylogeny and evolution of Perezia (Asteraceae: mutisieae: nassauviinae). J. Syst. Evol. 47, 431-443. doi: 10.1111/j.1759-6831.2009.00039.x

Sklenár, P., and Balslev, H. (2007). Geographic flora elements in the Ecuadorian Superpáramo. Flora 202, 50-61. doi: 10.1016/j.flora.2006.03.002

Sklenář, P., Luteyn, J. L., Ulloa Ulloa, C., Jørgensen, P. M., and Dillon, M. O. (2005). Flora genérica des los Páramos: guía ilustrada de las plantas vasculares. Mem. N.Y. Bot. Gard. 92, 1-499.

Smith, L. B. (1962). Origins of the flora of southern Brazil. Contr. U.S. Natl. Herb. $35,215-249$.

Smith, R. B., and Evans, J. P. (2007). Orographic precipitation and water vapor fractionation over the Southern Andes. J. Hydrometeorol. 8, 3-19. doi: 10.1175/JHM555.1

Soejima, A., Wen, J., Zapata, M., and Dillon, M. O. (2008). Phylogeny and putative hybridization in the subtribe Paranepheliinae (Liabeae, Asteraceae), implications for classification, biogeography, and Andean orogeny. J. Syst. Evol. 46, 375-390. doi: 10.3724/SP.J.1002.2008.08065

Stern, L. A., and Blisniuk, P. M. (2002). Stable isotope composition of precipitation across the southern Patagonian Andes. J. Geophys. Res. Atmos. 107, ACL 3-1ACL 3-14. doi: 10.1029/2002JD002509

Struwe, L., Haag, S., Heiberg, E., and Grant, J. R. (2009). Andean speciation and vicariance in Neotropical Macrocarpaea (Gentianaceae-Helieae). Ann. Missouri Bot. Gard. 96, 450-469. doi: 10.3417/2008040

Susanna, A., Galbany-Casals, M., Romaschenko, K., Barres, L., Martín, J., and Garcia-Jacas, N. (2011). Lessons from Plectocephalus (Compositae, CardueaeCentaureinae): ITS disorientation in annuals and Beringian dispersal as revealed by molecular analyses. Ann. Bot. 108, 263-277. doi: 10.1093/aob/ $\operatorname{mcr} 138$

Symmank, L., Samain, M.-S., Smith, J. F., Pino, G., Stoll, A., Goetghebeur, P., et al. (2011). The extraordinary journey of Peperomia subgenus Tildenia (Piperaceae): insights into diversification and colonization patterns from its cradle in Peru to the Trans-Mexican volcanic belt. J. Biogeogr. 38, 2337-2349. doi: 10.1111/j.1365-2699.2011.02586.x

Tate, J. A., Fuertes Aguilar, J., Wagstaff, S. J., Duke, J. C. L., Bodo Slotta, T. A., and Simpson, B. B. (2005). Phylogenetic relationships within the tribe Malveae (Malvaceae, subfamily Malvoideae) as inferred from ITS sequence data. Am. J. Bot. 92, 584-602. doi: 10.3732/ajb.92.4.584

Tate, J. A., and Simpson, B. B. (2003). Paraphyly of Tarasa (Malvaceae) and diverse origins of the polyploid species. Syst. Bot. 28, 723-737. doi: 10.1043/02-64.

Tate, J. A., and Simpson, B. B. (2004). Breeding system evolution in Tarasa (Malvaceae) and selection for reduced pollen grain size in the polyploid species. Am. J. Bot. 91, 207-213. doi: 10.3732/ajb.91.2.207

Trénel, P., Gustafsson, M. H. G., Baker, W. J., Asmussen-Lange, C. B., Dransfield, J., and Borchsenius, F. (2007). Mid-Tertiary dispersal, not Gondwanan vicariance explains distribution patterns in the wax palm subfamily (Ceroxyloideae: Arecaceae). Mol. Phylogenet. Evol. 45, 272-288. doi: 10.1016/j.ympev.2007.03.018

Troll, C. (1968). The cordilleras of the tropical Americas. Aspects of climatic, phytogeographical and agrarian ecology. Colloq. Geogr. 9, 15-56.

Ulibarri, E. A. (2005). Zuccagnia punctata (Leguminosae): ¿nuevo o viejo endemismo argentino? Darwiniana 43, 212-215.

van der Hammen, T. (1974). The Pleistocene changes of vegetation and climate in tropical South America. J. Biogeogr. 1, 3-26. doi: 10.2307/3038066

van der Hammen, T., and Cleef, A. M. (1983). Datos para la historia de la flora andina. Rev. Chil. Hist. Nat. 56, 97-107.
Vargas, O. M., and Madriñán, S. (2012). Preliminary phylogeny of Diplostephium (Asteraceae): speciation rate and character evolution. Lundellia 15, 1-15.

Vasco, A., Moran, R. C., and Rouhan, G. (2009). Circumscription and phylogeny of the Elaphoglossum ciliatum group (E. sect. Lepidoglossa, Dryopteridaceae) based on cpDNA sequences. Taxon 58, 825-834.

Villagrán, C., Arroyo, M. T. K., and Marticorena, C. (1983). Efectos de la desertización en la distribución de la flora andina de Chile. Rev. Chil. Hist. Nat. 56, 137-157.

von Hagen, K. B., and Kadereit, J. W. (2001). The phylogeny of Gentianella (Gentianaceae) and its colonization of the southern hemisphere as revealed by nuclear and chloroplast DNA sequence variation. Org. Divers. Evol. 1, 61-79. doi: 10.1078/1439-6092-00005

von Hagen, K. B., and Kadereit, J. W. (2003). The diversification of Halenia (Gentianaceae): ecological opportunity versus key innovation. Evolution 57, 2507-2518. doi: 10.1111/j.0014-3820.2003.tb01495.x

Vuilleumier, B. S. (1971). Pleistocene changes in the fauna and flora of South America. Science 173, 771-780. doi: 10.1126/science.173.3999.771

Wagner, N., Silvestro, D., Brie, D., Ibisch, P. L., Zizka, G., Weising, K., et al. (2013). Spatio-temporal evolution of Fosterella (Bromeliaceae) in the Central Andean biodiversity hotspot. J. Biogeogr. 40, 869-880. doi: 10.1111/jbi.12052

Weigend, M. (2002). Observations on the biogeography of the AmotapeHuancabamba Zone in northern Peru. Bot. Rev. 68, 38-54. doi: 10.1663/00068101(2002)068[0038:OOTBOT]2.0.CO;2

Weigend, M. (2004). Additional observations on the biogeography of the AmotapeHuancabamba zone in northern Peru - Defining the south-eastern limits. Rev. Peru. Biol. 11, 127-134.

Weigend, M., Cano, A., and Rodríguez, E. F. (2005). New species and new records of the flora of the Amotape-Huancabamba zone: Endemics and biogeographic limits. Rev. Peru. Biol. 12, 185-194.

Weigend, M., Gottschling, M., Hilger, H. H., and Nürk, N. M. (2010). Five new species of Lithospermum L. (Boraginaceae tribe Lithospermeae) in Andean South America: another radiation in the Amotape-Huancabamba zone. Taxon $59,1161-1179$.

Weigend, M., Gottschling, M., Selvi, F., and Hilger, H. H. (2009). Marbleseeds are gromwells - Systematics and evolution of Lithospermum and allies (Boraginaceae tribe Lithospermeae) based on molecular and morphological data. Mol. Phylogenet. Evol. 52, 755-768. doi: 10.1016/j.ympev.2009.05.013

Wen, J., Zhang, J.-Q., Nie, Z.-L., Zhong, Y., and Sun, H. (2014). Evolutionary diversifications of plants on the Qinghai-Tibetan Plateau. Front. Genetics 5:4. doi: 10.3389/fgene.2014.00004

Young, K. R., Ulloa, C. U., Luteyn, J. L., and Knapp, S. (2002). Plant evolution and endemism in Andean South America: an introduction. Bot. Rev. 68, 4-21. doi: 10.1663/0006-8101(2002)068[0004:PEAEIA]2.0.CO;2

Zachos, J., Pagani, H., Sloan, L., Thomas, E., and Billups, K. (2001). Trends, rhythms, and aberrations in global climate $65 \mathrm{Ma}$ to present. Science 292, 686-693. doi: 10.1126/science.1059412

Zachos, J. C., Dickens, G. R., and Zeebe, R. E. (2008). An early Cenozoic perspective on greenhouse warming and carbon-cycle dynamics. Nature 451, 279-283. doi: $10.1038 /$ nature 06588

Conflict of Interest Statement: The authors declare that the research was conducted in the absence of any commercial or financial relationships that could be construed as a potential conflict of interest.

Received: 31 March 2014; paper pending published: 05 May 2014; accepted: 31 May 2014; published online: 19 June 2014.

Citation: Luebert F and Weigend M (2014) Phylogenetic insights into Andean plant diversification. Front. Ecol. Evol. 2:27. doi: 10.3389/fevo.2014.00027

This article was submitted to Evolutionary and Population Genetics, a section of the journal Frontiers in Ecology and Evolution.

Copyright (c) 2014 Luebert and Weigend. This is an open-access article distributed under the terms of the Creative Commons Attribution License (CC BY). The use, distribution or reproduction in other forums is permitted, provided the original author(s) or licensor are credited and that the original publication in this journal is cited, in accordance with accepted academic practice. No use, distribution or reproduction is permitted which does not comply with these terms. 